\title{
Analyzing Wrongful Convictions Beyond the Traditional Canonical List of Errors, for Enduring Structural and Sociological Attributes, (Juveniles, Racism, Adversary System, Policing Policies)
}

Leona D. Jochnowitz

Tonya Kendall

Follow this and additional works at: https://digitalcommons.tourolaw.edu/lawreview

Part of the Criminal Law Commons, Law and Society Commons, and the Social Control, Law, Crime, and Deviance Commons

\section{Recommended Citation}

Jochnowitz, Leona D. and Kendall, Tonya (2021) "Analyzing Wrongful Convictions Beyond the Traditional Canonical List of Errors, for Enduring Structural and Sociological Attributes, (Juveniles, Racism, Adversary System, Policing Policies)," Touro Law Review. Vol. 37: No. 2, Article 6.

Available at: https://digitalcommons.tourolaw.edu/lawreview/vol37/iss2/6

This Article is brought to you for free and open access by Digital Commons @ Touro Law Center. It has been accepted for inclusion in Touro Law Review by an authorized editor of Digital Commons @ Touro Law Center. For more information, please contact Iross@tourolaw.edu. 


\title{
ANALYZING WRONGFUL CONVICTIONS BEYOND THE Traditional CANONICAL LIST OF ERRORS, FOR ENDURING STRUCTURALAND SOCIOLOGICAL ATTRIBUTES, (JUVENILES, RaCisM, AdVErsary System, Policing Policies)
}

\author{
Leona D. Jochnowitz* \\ Tonya Kendall ${ }^{* *}$
}

\begin{abstract}
:
Researchers identify possible structural causes for wrongful convictions: racism, justice system culture, adversary system, plea bargaining, media, juvenile and mentally impaired accused, and wars
\end{abstract}

\footnotetext{
* Leona D. Jochnowitz earned a J.D. from St. John's University School of Law and an M.A and a Ph.D. from the School of Criminal Justice at the University at Albany. She is a member of the New York and Oregon State Bars and the federal bars. She currently serves as a Public Defender at Intermountain Public Defenders in Pendleton, Oregon and she also served on the Oregon COVID Habeas Corpus Task Force. Until May 2020, she was an Assistant Public Defender for Appeals and Parole Revocation in Albany County, New York. Previously, she served as an Assistant Professor of Criminal Justice at Curry College in Milton, Massachusetts and at other institutions where she taught courses on restorative justice, the death penalty, and wrongful convictions. Her research involves the death penalty, capital juror decision-making, mental health and intellectual disability defenses, and the structural causes of wrongful convictions. She has served as the book review editor for the Criminal Law Bulletin since 2014. The authors are very grateful to Dr. Gary Kowaluk, J.D., Ph.D., for his advice and expertise in finalizing this paper. The authors also wish to acknowledge and thank the student editors and faculty advisors of the Touro Law Review for their insight, extensive analysis, and recommendations in editing the article and in finalizing its publication.

** Tonya Kendall holds an M.A. in Restorative Justice and is a 2022 J.D. candidate at Vermont Law School. Ms. Kendall, who originally coded much of the data as a student at Northern Vermont University, worked intensively on this study, including analyzing the archival data for the Ollins and Bloodsworth cases and the structured interview data.
} 
on drugs and crime. They indicate that unless the root causes of conviction error are identified, the routine explanations of error (e.g., eyewitness identifications; false confessions) will continue to re-occur. Identifying structural problems may help to prevent future wrongful convictions. The research involves the coding of archival data from the Innocence Project for seventeen cases, including the one for the Central Park Five exonerees. The data were coded by Hartwick College and Northern Vermont University students in their respective wrongful convictions courses. Students also designed a vignette of their case and conducted structured interviews with public officers, judges, lawyers, and investigators which inquired into the subjects' awareness of exonerations. A follow-up study, which is the subject of a future publication, was conducted with students at Curry College in Boston in 2019, many of whom worked as Boston City Police Officers and in other law enforcement occupations. The officers added their expertise and their appreciation of structural problems like justice system culture. This study emphasizes that the errors we see within the criminal justice system mirror and amplify the problems we see outside of that system. The findings here show that canonical list of errors in these cases may be just a veneer for deeper structural problems. 


\section{INTRODUCTION}

During the past century, legal scholars have identified the "causes" of wrongful conviction error. This is currently known as the traditional "canonical list of errors," "the catalog of errors," or "the familiar plot." 1 These errors have the effect of penalizing innocent persons for crimes they did not commit. The canonical list identifies what has gone wrong in the criminal justice system, but it often ignores the root causes of the errors which would be important to prevent future errors. The routine canonical list of errors includes eyewitness misidentification, invalidated forensic science, false confessions by juveniles and adults, government misconduct, snitches, and bad lawyering. Recently, scholars have tried to explain wrongful conviction error by identifying how more meaningful, deep structural problems in our society lead to these errors and wrongful convictions. These include racism, gender bias, social class inequality, stop and frisk policies, justice system culture, media, the adversary system, plea bargaining, coercive interrogations of juveniles and intellectually impaired persons, the punitive wars on drugs and crime, and cognitive biases like tunnel vision. ${ }^{2}$

Although scholars have commented that understanding the structural causes of wrongful convictions will help to identify and may help resolve the large contexts which lead to wrongful conviction

${ }^{1}$ Richard A. Leo, Rethinking the Study of Miscarriages of Justice: Developing a Criminology of Wrongful Conviction, 21 J. CONTEMP. CRIM. JUST. 201, 207 (2005); William Lofquist, Finding the Causes in Contexts: Structural Sources of Wrongful Convictions, in EXAMINING Wrongful Convictions: STEPPING BACK, MOVInG FORWARD 19, 21 (Allison D. Redlich et al. eds., 2014) [hereinafter EXAMINING WRONGFUL CONVICTIONS].

${ }^{2}$ Hannah Laqueur et al., Wrongful Convictions, Policing and the "Wars on Crime and Drugs," in EXAMINING WRONGFUL CONVICTIONS, supra note 1, at 93; Lofquist, supra note 1, at 19-34; Cynthia Najdowski, Interactions Between African Americans and Police Officers: How Cultural Stereotypes Create a Wrongful Conviction Pipeline for African Americans, in EXAMINING WRONGFUl Convictions, supra note 1, at 55-70; Barbara O'Brien \& Keith Findley, Psychological Perspectives: Cognition and Decision Making, in EXAMINING WRONGFUL CONVICTIONS, supra note 1, at 35-54; Steven Drizin et al., Juvenile Justice Investigation: Narrative Contamination, Cultural Stereotypes, and the Scripting of Juvenile False Confessions, in EXAMINING Wrongful CONVICTIONS, supra note 1, at 169-88; Martin Yant, The Media's Muddled Message on Wrongful Convictions, in EXAMINING WRONGFul Convictions, supra note 1, at 71-92; see Cynthia J. Najdowski et al., Stereotype Threat and Racial Differences in Citizens' Experiences of Police Encounters, 39 L. \& HUM. BEHAV. 463, 463 (2015). 
susceptibility, ${ }^{3}$ there is little systematic research focusing on this issue. In other words, the methodology for uncovering structural causes has lagged behind the theory. Until now, even the Innocence Project identified the sources of measurable canonical error as "misidentification, forensic errors, false confessions, and use of informants." The present research addresses this gap in knowledge by using original trial transcript data and structured interviews that go beyond secondary sources and media in notorious and other cases to show the structural reasons leading to the conviction of innocent persons. In other words, this study reveals that the errors we see within the criminal justice system mirror and amplify the problems we see outside of that system.

In addition to its contributions to the research, the present study also models an effective way to integrate research into undergraduate teaching. Indeed, because students initially coded court transcripts and did structured interviews, the present project not only effectively links research and teaching but also provides a forum for budding scholars to present their fresh insights. ${ }^{5}$

\footnotetext{
${ }^{3}$ Lofquist, supra note 1, at 21-22.

${ }^{4}$ Robert J. Norris et al., The Criminal Costs of Wrongful Convictions: Can We Reduce Crime by Protecting the Innocent?, 19 CRIMINOLOGY \& PUB. POL'Y. 1, 12 (2019); Emily West \& Vanessa Meterko, Innocence Project: DNA Exonerations, 1989-2014: Review of Data and Findings from the First 25 Years, 79 ALB. L. REV. 717, 718 (2016).

5 The student authors did the following research for this project: coding the trial transcripts and completing the interviews discussed in the text below. Tonya Kendall and Fadhilia Achinda, Northern Vermont University, coded the Ollins trial transcripts and interviewed Vermont State Attorney (PF). Debra Fulton, Northern Vermont University coded the Bloodsworth and Korey Wise (Central Park Five defendant) trial transcripts and interviewed U.S. Senator Patrick Leahy.

Amber Burke and Courtney Currier, Northern Vermont University, coded the Bloodsworth trial transcripts and interviewed Vermont State Senator Joseph Benning, from the Caledonia District. Amber Burke recently graduated in 2021 from New England Law School in Boston. Melanie Velarde, Northern Vermont University, coded the Larry Youngblood trial transcript. At Hartwick College, Sheryl Hugh, Hartwick College, coded the Yusef Salaam trial transcript and interviewed Vanessa Meterko of the Innocence Project. Ms. Hugh is now a graduate student for her MSW at NYU and a Social Work intern. Alaysha Walker and Kiley Richardson, Hartwick College, coded the Earl Washington clemency documents and interviewed Washington's clemency attorney, Barry Weinstein, regarding his case. Katherine Pooters and Candace Barrow, Hartwick College, coded the Korey Wise and Kevin Richardson (Central Park Five defendants) trial transcripts.
} 


\section{History AND The CURRent State OF Research}

For purposes of this article, we adopt the definition of wrongful convictions previously offered by Norris, Bonventre, and Acker: "cases in which individuals are innocent of wrongdoing and have erroneously [or maliciously] been convicted: (a) for crimes committed by someone else ("wrong-person" cases); or (b) when no crime at all actually was committed ("no crime" cases)." 6

Scholars state that unless the root sociological causes of conviction error are identified, the currently recognized causes of error will continue to re-occur.

Finding the social structural causes of wrongful convictions thus involves identifying the larger contexts in which particular groups become vulnerable to being defined as suspects, to being arrested, and to having their arrests transformed into convictions, despite the absence of evidence to support that conviction in a reliable adjudicatory process. $^{7}$

Stop and frisk strategies, hot spots policing, and undercover operations continue to place residents of heavily policed neighborhoods at high risk of arrest without robust evidentiary investigation.

In 2005, Richard Leo identified what he called the "familiar plot" of wrongful conviction scholarship. ${ }^{8}$

This [] plot . . . usually begins with a harrowing, if unlikely, story of an innocent man (and it almost always is a man) who was unjustly accused and arrested for a heinous, high-profile crime he almost certainly did not commit. The arrested innocent was then prosecuted by a hard-charging district attorney and eventually convicted by jury trial, only later to be exoneratedtypically as a result of the sustained, at times heroic, efforts of someone or some group outside the criminal justice system - and eventually released from prison, sometimes even from death row. The exoneration and

\footnotetext{
${ }^{6}$ ROBERT J. NORRIS ET AL., WhEN JUSTICE FAILS: CAUSES AND CONSEQUENCES OF WRONGFUl CONVICTIONS 5 (2018).

${ }^{7}$ Lofquist, supra note 1, at 22-23.

${ }^{8}$ Leo, supra note 1 , at 207.
} 
release often occurred only after many years of incarceration and unjust suffering. ${ }^{9}$

Leo noted that the "familiar plot is so familiar by now that it has become largely an intellectual dead end." 10 Indeed, books about wrongful conviction injustices are often so repetitive that they offer little new insight or understanding. Leo, therefore, predicted that the formula for such books "will be little different 40 years from now as it is today or was 40 years ago." 11 Leo, therefore, proposed developing a new criminology for the study of wrongful convictions which transcended a "familiar plot" and instead examined theoretically informed root sociological cases. ${ }^{12}$

In keeping with the search for a new criminology of wrongful convictions, social movement scholar Norris, in 2017, describes the Innocence Movement as representing part of a broad social reform perspective which advances social and legal justice. ${ }^{13}$ Wrongful convictions allow you to see "fundamental issues like race, authority, and the relationship between citizen and state" more clearly, and "[d]ebates over the war on drugs and mass incarceration ... are intimately [tied] to conversations about race, class, families, and neighborhoods." 14 All these factors, race, class, gender, the war on crime, and mass incarceration, impact the extent to which people receive justice.

Still, no one can dispute the fact that important reforms can reduce canonical conviction errors. These include reforms for eyewitness identification (double blind line-ups), interrogation (protection for juveniles and videotaping the entire process), proposals to make forensic laboratories more accountable and independent from law enforcement, more accountability and disclosure by prosecutors and police officers, preservation of evidence, better defense funding, increasing informant reliability, and restorative and monetary compensation for exonerees. ${ }^{15}$

\footnotetext{
${ }^{9} I d$.

${ }^{10} \mathrm{Id}$.

${ }^{11} \mathrm{Id}$.

${ }^{12} \mathrm{Id}$. 293 (2019).

55 CRIM. L. BULL. 1, 1 (2019).

${ }^{14}$ NORRIS, supra note 13 , at 175.

${ }^{15}$ NORRIS ET AL., supra note 6, at 228-32.
}

${ }^{13}$ See Robert J. Norris, EXONERATED: A History OF THE INNOCENCE MOVEMENT 174-79 (2017); see also Leona D. Jochnowitz, Book Review, 55 CRIM. L. BULL. 292, 
In his work on the contextual and structural causes of wrongful convictions, Lofquist analyzed the so-called "Central Park Five." This notorious case involved the wrongful convictions of five black teenagers accused of raping a jogger in New York City's Central Park in 1989. At first blush, the issue in the case may appear to be the teenagers' false confessions, but the real structural issue is why these boys were singled out for arrest in the first place. The answer involves racial profiling, zero-tolerance law enforcement policies, and the way in which young, black males perceive threat and punishment. ${ }^{16}$ Lofquist describes the vulnerability of the Central Park Five teens:

The defendants in this case were vulnerable to wrongful convictions. Their vulnerability was much more a product of who they were and the relationships between their community and the criminal justice system, than of the particular circumstances of their cases .... They were the usual crime subjects before they were the usual rape subjects. ${ }^{17}$

Reviewing which of the catalogue of errors occurred here does not shed light on understanding the wrongful convictions. Aside from race, wrongful convictions arise from other systemic flaws such as tunnel vision in police and prosecutor decision making, media biased coverage, electoral politics, and mistreatment of juveniles. As seen below, many falsely accused are white.

The study of wrongful convictions is also an extension of the general social scientific study of decision-making error and the biases of human reasoning. ${ }^{18}$ Decision-makers use heuristic shortcuts like "simplification, dissonance reduction, stereotyping and consonance amplification," as aids to problem solving which can result in hindsight bias and tunnel vision in criminal cases. ${ }^{19}$ Wrongful convictions usually result from a combination of errors, rather than one mistake, which lead to the conviction of innocent persons. These persons may

\footnotetext{
${ }^{16}$ Najdowski, supra note 2, at 55-70; Najdowski et al., supra note 2, at 56-59.

${ }^{17}$ Lofquist, supra note 1 , at 22.

${ }^{18}$ Daniel Kahneman, Thinking, FAST AND Slow 3-8 (2013); Nancy Pennington \& Reid Hastie, The Story Model for Juror Decision Making, in INSIDE THE JUROR: THE PSYCHOLOGY OF JUROR DECISION MAKING 192 (Reid Hastie ed., 1993); https://onbeing.org/programs/daniel-kahneman-why-we-contradict-ourselves-andconfound-each-other/.

${ }^{19}$ William J. Bowers, The Capital Jury Project: Rationale, Design and Preview of Early Findings, 70 IND. L.J. 1043, 1069 (1995).
} 
be exonerated many years later through the introduction of new forensic and witness evidence revealing errors. ${ }^{20}$ These acts may take years to uncover, and even then, convictions are difficult to overturn, and officials are often insulated and immune from legal remedies. ${ }^{21}$ Moreover, after a wrongful conviction is set aside, exonerees receive fewer services than parolees who are under reentry supervision, such as assistance finding jobs and housing placements. ${ }^{22}$

\section{A. The Prevalence of Wrongful Convictions}

There are at least two commonly used data sources for wrongful convictions: The Innocence Project ${ }^{23}$ and the National Registry of Exonerations. ${ }^{24}$ The former focuses on DNA exonerations based on the strategic decision by founders Peter Neufeld and Barry Scheck to formulate policy with indisputable cases. ${ }^{25}$ Since the first DNA exoneration in 1989 and late 2020, the Innocence Project has helped 375 wrongfully convicted persons in thirty-seven states. ${ }^{26}$

According to the National Registry of Exonerations, more than 2,710 persons were exonerated between 1989 and May 8, 2021, 582 (DNA) and 2214 (non-DNA). ${ }^{27}$ However, exoneration cases might only begin to scratch the surface of persons who have been erroneously

${ }^{20}$ See James R. Acker et al., Stepping Back-Moving Beyond Immediate Causes: Criminal Justice and Wrongful Convictions in Social Context, in EXAMINING WRONGFUL CONVICTIONS, supra note 1 , at 3.

${ }^{21}$ See, e.g., Connick v. Thompson, 563 U.S. 51, 61 (2011); Arizona v. Youngblood, 488 U.S. 51, 73 (1988). For a discussion of these cases, see NORRIS ET AL., supra note 6 , at $129-32$.

${ }^{22}$ See NORRIS ET AL., supra note 6, at 201.

${ }^{23}$ INNOCENCE PROJECT, https://www.innocenceproject.org/ (last visited Dec. 17, 2020).

24 NAT'L REGISTRY OF EXONERATIONS, http://www.law.umich.edu/special/exoneration/Pages/about.aspx (last visited Dec. 17, 2020) [hereinafter NRoE].

${ }^{25}$ See NORRIS, supra note 13, at 56 ("' $[\mathrm{Y}]$ ou want cases that are simply noncontroversial, where everyone agrees - prosecution, judges, the defense- that these people are stone cold innocent."). The author is quoting his interview of Peter Neufeld. Id.

26 DNA Exonerations in the United States, INNOCENCE PROJECT, https://innocenceproject.org/dna-exonerations-in-the-united-states/ (last visited Dec. 17, 2020).

27 Exonerations by Year: DNA and Non-DNA, NRoE, http://www.law.umich.edu/special/exoneration/Pages/Exoneration-by-Year.aspx (last visited May 8, 2021). 
convicted because prejudicial errors in an unknown number of other cases may not yet have been discovered. ${ }^{28}$ Thus, the prevalence of wrongful convictions, including wrongful plea bargaining, is not known. But in light of the number of known exonerations compared against known felony cases, scholars estimate an error rate between $0.5 \%$ and $1.0 \%$, which means that upwards of 2,500 innocent people may be sent to prison each year. ${ }^{29}$ The error rate may even be higher in death penalty cases, with some scholars estimating that as many as $4.1 \%$ of persons sentenced to death in the post-Furman/Gregg ${ }^{30}$ era have been wrongfully convicted. ${ }^{31}$

Keeping in mind that many wrongful conviction cases have multiple contributing causes, the factors that have been documented as contributing to specific wrongful convictions include the following:

1. Perjury or False Accusation: $58 \%$; highest in child sex abuse cases (84\%) and homicide cases (70\%)

2. Official Misconduct (police and prosecutorial): $54 \%$; highest in homicide cases $(71 \%)$

\footnotetext{
${ }^{28}$ NORRIS ET AL., supra note 6, at 6-9.

29 See, e.g., Marvin Zalman, Qualitatively Estimating the Incidence of Wrongful Convictions, 48 CRIM. L. BuLl. 221, 229 (2012); cf. Ronald J. Allen \& Larry Laudan, Deadly Dilemmas, 41 TEX. TECH L. REV. 65, 71 (2008) (estimating a 0.84\% error rate); Brandon L. Garrett, Convicting the InNOCEnt: Where CRiminal PROSECUTIONS Go Wrong 264 (2011) (estimating a 2.7\% error rate); Samuel Gross, Convicting the Innocent, 4 ANN. REV. L. \& SoC. SCI. 173, 176 (2008) (estimating an error rate between $1 \%$ and $7 \%$ ); LARRY LAUDAN, THE LAW'S FLAWS: RETHINKING TRIALS AND ERRORS? 54 (2016) (calculating a mean estimate, using other studies, of a $3.25 \%$ wrongful conviction rate); D. Michael Risinger, Innocents Convicted: An Empirically Justified Factual Wrongful Conviction Rate, 97 J. CRIM. L. \& CRIMINOLOGY 761, 762 (2007) (estimating a 3.3\% error rate); DAN SIMON, IN Doubt: The Psychology of The CRiminal Justice Process 226 n.12 (2012) (extrapolating an error rate between 3\% and 4\%); but see Paul G. Cassell, Overstating America's Wrongful Conviction Rate? Reassessing the Conventional Wisdom About the Prevalence of Wrongful Convictions, 60 ARIZ. L. REV. 815, 815 (2018) (criticizing all of these estimates and calculating and error rate between $0.016 \%$ and $0.062 \%)$.

${ }^{30}$ Gregg v. Georgia, 428 U.S. 153, 182 (1976); Furman v. Georgia, 408 U.S. 238, 364-66 (1972).

${ }^{31}$ See, e.g., Samuel R. Gross, et al., Rate of False Conviction of Criminal Defendants who are Sentenced to Death, 111 PROC. NAT'L ACAD. SCI. 7230, 7230 (2014); EXAMINING WRONGFUL CONVICTIONS, supra note 1, at 3, 251, 256-57.
} 
3. Mistaken Witness Identification: $28 \%$; highest in sexual assault cases $(66 \%)$

4. False or Misleading Forensic Evidence: 23\%; highest in sexual assault cases (30\%); and

5. False Confessions: 12\%; highest in homicide cases $(23 \%) .{ }^{32}$

The rate of false confessions is particularly troubling for youthful defendants. Of the Innocence Project's DNA exonerees, " $49 \%$ of false confessors were twenty-one-years-old or younger at the time of arrest;" a third were age eighteen or younger. ${ }^{33}$

Demographically, $91 \%$ of exonerees are male and $62.7 \%$ of exonerees are from racial or ethnic minority backgrounds $(48.8 \%$ Black; $11.6 \%$ Hispanic; $2.3 \%$ Native American, Asian, or race/ethnicity). ${ }^{34}$ Homicide cases account for the highest percentage (38\%) of wrongful conviction cases, with other common crime types including sexual assaults (13\%), drug cases (13\%), child sex abuse $(11 \%)$, and robbery $(5 \%) .{ }^{35}$ All told, these exonerees spent nearly 21,726 years in prison. ${ }^{36}$

\section{B. Racial Profiling and Stereotyping}

The aggressive use of stop-and-frisk as part of widespread, crime-control strategies in New York City and other major cities did more than damage police legitimacy in many urban areas. ${ }^{37}$ The racial profiling that was part and parcel of such stop-and-frisk strategies contributed to wrongful convictions because members of minority groups were vulnerable to being targeted as suspects, leading to arrests

$32 \%$ Exonerations by Contributing Factor, NRoE, http://www.law.umich.edu/special/exoneration/Pages/ExonerationsContribFactorsB yCrime.aspx (last visited Jan. 17, 2021).

${ }_{33}^{33}$ DNA Exonerations in the United Stated, supra note 27.

34 Exonerations by Race/Ethnicity and Crime, NRoE, http://www.law.umich.edu/special/exoneration/Pages/ExonerationsRaceByCrime.a spx (last visited Jan. 17, 2021).

35 Exonerations in the United States Map, NRoE, http://www.law.umich.edu/special/exoneration/Pages/Exonerations-in-the-UnitedStates-Map.aspx (last visited January 21, 2021).

${ }^{36} I d$.

${ }^{37}$ See Michael D. White \& Henry F. Fradella, Stop and Frisk: The Use And ABUSE OF A CONTROVERSIAL POLICING TACTIC 7 (2016). 
and false convictions. ${ }^{38}$ As Lofquist noted, black teens in Harlem were targeted more because of who they were rather than what they did. ${ }^{39}$ As indicated above, structural problems of poverty and race arise in all sectors of society and are applicable in criminal justice and wrongful convictions. The criminological focal-concerns perspective suggests that "harsher treatment results from stereotypes of racial minorities as more dangerous, more culpable, and less amenable to rehabilitation." 40 This perspective may explain the structural causes of wrongful convictions by police, prosecutors, judges, and jurors here.

Race may be an important factor for understanding why innocent individuals enter the justice system in the first place, and race leads to errors regarding perception of threat. ${ }^{41}$ One of the explanations for race discrimination leading to wrongful convictions is the theory of stereotype threat. This is when both law enforcement and minority citizens interact in a threatened and fearful manner, and police mistakenly interpret the behavior as "furtive" or suspicious. Najdowski theorizes that stereotype threat-induced nervous behaviors may be misinterpreted by police officers as "furtive movements." 42 Yet, the court in Floyd $v$. City of New York ${ }^{43}$ concluded that " $[\mathrm{t}]$ here is no evidence that black people's movements are more furtive than the movements of white people." ${ }^{4}$ Similarly, race discrimination is found in statistical evidence of disproportionate traffic stops against AfricanAmerican motorists. ${ }^{45}$ Yet there is nothing in the literature to support the theory that blacks drive differently from whites, despite higher proportions of stops for African Americans. ${ }^{46}$ Data regarding the volume of minorities singled out can also help explain why innocent

\footnotetext{
${ }^{38}$ Floyd v. City of New York, 959 F. Supp. 2d 540, 558-60, $572-73$ (S.D.N.Y. 2013).

${ }^{39}$ Lofquist, supra note 1, at 22-23.

${ }^{40}$ Cassia Spohn, Race, Crime, and Punishment in the Twentieth and Twenty-First Centuries, 44 CRIME \& JusT. 49, 91 (2015); Darrell Steffensmeier et al., The Intersection of Race, Gender, and Age in Criminal Sentencing: The Punishment Cost of Being Young, Black, and Male, 36 CRIMINOLOGY 763, 779 (1998); see Leona D. Jochnowitz, Book Review (Juvenile LWOP and the Death Penalty), 56 CRIM. L. BULL. (2020).

${ }^{41}$ Najdowski, supra note 2, at 57.

${ }^{42} \mathrm{Id}$. at 63; Najdowski et al., supra note 2, at 474-75.

${ }^{43}$ Floyd v. City of New York, 959 F. Supp. 2d 540, 581 (S.D.N.Y. 2013).

${ }^{44} I d$. at 581.

${ }^{45}$ State v. Soto, 734 A.2d 350, 355 (N.J Super. Ct. Law Div. 1996).

${ }^{46}$ Id. ("Dr. James Fyfe, a criminal justice professor at Temple . . . also testified that there is nothing in the literature or in his personal experience to support the theory that blacks drive differently from whites.").
} 
minority youth enter the justice system in the first place. The fact that $62.7 \%$ of exonerees are from racial or ethnic backgrounds may help explain wrongful conviction data. ${ }^{47}$

Racial stereotyping, confirmation bias, and tunnel vision are the sources of most of the factors (traditional and root) leading to wrongful convictions. Stereotyping comes from unconscious or conscious biases that affect how people process information. Police may be more easily convinced of a suspect's guilt when it conforms to their stereotypes, thus pursuing evidence that confirms rather than dispels their suspicions. ${ }^{48}$ In some geographic areas, stereotyping may apply to other racial minorities like Native Americans and Hispanics.

The recent COVID-19 Pandemic has made clear that the structural problems of poverty and race arise in all sectors and are affected by where people live, their access to transportation and education and are applicable in criminal justice and wrongful convictions. More minorities are essential workers and end up hospitalized due to COVID-19. ${ }^{49}$ More minorities have been stopped by police when they are enforcing social distancing and mask mandates during the pandemic. ${ }^{50}$ The Pandemic lockdown was

${ }^{47}$ Exonerations by Race/Ethnicity and Crime, supra note 35 (48.8\% Black; $11.6 \%$ Hispanic; 2.3\% Native American, Asian, or race/ethnicity); Samuel R. Gross et al., Race and Wrongful Convictions in the United States, NRoE (Mar. 7, 2017), http://www.law.umich.edu/special/exoneration/Documents/Race_and_Wrongful_C onvictions.pdf ("African Americans are only 13\% of the American population but a majority of innocent defendants wrongfully convicted of crimes and later exonerated.").

${ }^{48}$ O'Brien \& Findley, supra note 2, at 36; Andrew E. Taslitz, Wrongly Accused: Is Race a Factor in Convicting the Innocent?, 4 OHIO STATE J. CRIM. L. 121, 126 (2006) ("There is ample data showing that whites generally believe that African-Americans are more violent than whites.").

${ }^{49}$ Roni Caryn Rabin, Black Coronavirus Patients Land in Hospitals More Often, Study Finds, N.Y. TIMES (May 23, 2020), https://www.nytimes.com/2020/05/23/health/coronavirus-blackpatients.html?searchResultPosition=2.

${ }^{50}$ Joseph Goldstein, Did Floyd Protests Lead to a Virus Surge? Here's What We Know, N.Y. TIMES (July 1, 2020), https://www.nytimes.com/2020/07/01/nyregion/nyc-coronavirus-protests.html;

NORRIS ET AL., supra note 6, at 179 ("All of the factors that impact what we see in criminal justice also affect wrongful convictions; race, class, gender, politics, and moral emotions all impact the extent to which people receive justice."); see Leona Jochnowitz, Book Review, 55 CRIM. L. BULL. 292, 293 (2019). 
followed by nationwide social justice demonstrations following the killing of George Floyd by Minneapolis police officers in Minnesota. ${ }^{51}$

\section{False Confessions and Failed Miranda Warnings}

Another risk factor for wrongful convictions is false confessions and failed Miranda warning understanding, particularly for juveniles. Juveniles are at risk for involuntary and false confessions in the interrogation room. Kassin and colleagues acknowledged that between 15 to $20 \%$ of DNA exonerations involve false confessions. ${ }^{52}$ They indicate that about $35 \%$ of false confessions are juveniles under eighteen, of which approximately 55\% are fifteen or younger. ${ }^{53}$ The risk factors for false confessions are age, "suggestibility, heightened obedience to authority, and immature decision-making." 54 Adolescents are cognitively less mature and prone to impulsive decision-making. They fail to consider the longterm consequences of decisions and engage in risky behaviors. Neurologically, the prefrontal cortex of the brain is not developed for planning, and they are prone to sensation seeking and emotional arousal that may induce false confessions. ${ }^{55}$ This is seen in the partially video-taped confessions by the Central Park Five and other youthful defendants in this study. The consequences of a false confession are that police close the investigation. The confession taints any other evidence, and it has the greatest impact on juries. ${ }^{56}$

Kassin and colleagues discuss factors which induce juveniles and adults into false confessions. ${ }^{57}$ Both situational factors and dispositional factors make persons vulnerable to false confessions. Situational factors include physical custody and isolation, false evidence, and implied promises. ${ }^{58}$ Dispositional Risk factors include

51 Former Minneapolis Police officer Derek Chauvin was convicted on April 21, 2021 in the murder of George Floyd in May, 2020. https://www.cnn.com/2021/04/23/us/derek-chauvin-sentencing-georgefloyd/index.html

52 Saul M. Kassin et al., Police-Induced Confessions: Risk Factors and Recommendations, 34 L. \& HUM. BEHAV. 3, 3 (2010).

53 Id. at 8.

${ }^{54}$ Id. at 19.

${ }^{55} \mathrm{Id}$.

${ }^{56} \mathrm{Id}$. at 23 .

${ }^{57} \mathrm{Id}$. at 4.

${ }^{58} \mathrm{Id}$. at $16-19$. 
adolescence, immaturity, and intellectual disability. ${ }^{59}$ Aside from overt third-degree practices of the past, investigators today use more subtle, yet psychologically coercive techniques on adults and juveniles. Reid and Inbau's interrogation tactics - which include maximization and minimization interrogation tactics, trickery and deception, compliance, and internalization-are commonplace. ${ }^{60}$ Scholars recommend that deceptive interrogation techniques should be omitted because juveniles are vulnerable to them. ${ }^{61}$

\section{Narrative Contamination and Cultural Stereotypes}

Drizin, Nirider, and Tepfer focus on cultural stereotypes and narrative contamination in the analysis of juvenile false confessions. ${ }^{62}$ Police investigators develop wrong hunches based on pervasive cultural stereotypes of race and age about the way teens act. Police develop narratives about bad teenagers. They stereotype minority urban teens as super predators. ${ }^{63}$ Similarly, police viewed the minority Central Park Five youth to be "super predators." 64 Reporters described the boys as symbols of an urban wolf pack, engaged in animalistic "wilding." 65 In addition, police stereotype white suburban teen loners. ${ }^{66}$ They are associated by the media as angry school shooters, influenced by violent video games and movies, based on the stereotype of the Columbine High School shooters, Eric Harris and Dylan Klebold. ${ }^{67}$ According to Drizin, fourteen-year-old Michael Crowe, from California, became a false suspect solely based on the cultural stereotype that he played video games. ${ }^{68} \mathrm{He}$ was falsely accused of killing his twelve-year-old sister in her bedroom, and investigators

\footnotetext{
${ }^{59} \mathrm{Id}$. at $19-22$.

${ }^{60} \mathrm{Id}$. at 12 .

${ }^{61} \mathrm{Id}$. at 19.

${ }^{62}$ Drizin et al., supra note 2, at 169; Joshua A. Tepfer et al., Convenient Scapegoats: Juvenile Confessions and Exculpatory DNA in Cook County, IL, 18 CARDOZO J.L. \& GENDER 631, 631-32 (2012).

${ }^{63}$ Drizin et al., supra note 2, at 170.

${ }^{64}$ See id.

65 BURNS, supra note 16 , at 117.

${ }^{66}$ Drizin et al., supra note 2, at 170.

${ }^{67}$ Craig A. Anderson \& Karen E. Dill, Video Games and Aggressive Thoughts, Feelings and Behavior in the Laboratory and in Life, 78 J. PERSONALITY \& SOC. PSYCH. 772, 772 (1999).

${ }^{68}$ Crowe v. Cnty. of San Diego, 608 F.3d 406, 41823. (9th Cir. 2010); Drizin et al., supra note 2 , at 174 .
} 
extracted untruthful, coerced confessions. ${ }^{69}$ After hours of interrogation, investigators McDonough and Clayton used discredited deceptive interrogation tactics, falsely claiming they found blood in his room. ${ }^{70}$ Michael repeatedly denied this, and then falsely confessed, sobbing that he did not remember the killing. ${ }^{71}$

\section{METHODS}

This is an exploratory study which researches the explanation for wrongful conviction error in the criminal justice system. The basic research question is: What are the explanations of wrongful conviction cases beyond the traditional canonical list of errors, which include more enduring structural and sociological explanations? The study examines the theory that enduring structural and sociological problems are common to wrongful conviction error, but they may be subtly referenced or hidden in public documents. Their identification may help to prevent future wrongful convictions. In other words, enduring structural and sociological problems may be common to and help identify the causes and the possible future prevention of wrongful convictions.

This research was generated uniquely by student research together with the author teaching wrongful convictions and qualitative methods at Hartwick College, Northern Vermont University (NVU, Johnson campus) and Curry College. The data here includes the systematic coding of trial transcripts from the Innocence Project and structured interviews with court participants and fellow students which was largely collected and initially analyzed by undergraduate students. $^{72}$

${ }^{69}$ Drizin et al., supra note 2, at 169.

${ }^{70}$ See Crowe, 608 F.3d at 419-20

${ }^{71} I d$. ("What - God. I don't — no. I don't know. I didn't do it. I swear to God. . . . God. God. Why? Why? Why? Oh, God. God. Why? Why? I don't deserve life. I don't want to live. I can't believe this. Oh, God. God. Why? Why? How could I have done this? I don't even remember if I did it. . . . How can I not remember doing something like that? That's not possible.").

${ }^{72}$ Baumgartner also used student collaboration with four undergraduate student researchers who took his courses in the decline of the death penalty taught at UNC Chapel Hill. The unique collaboration is described in his book's epilogue entitled "Teaching, Research and Teaching Research." FRANK R. BAUMGARTNER ET AL., DEADLY JUSTICE: A STATISTICAL PORTRAIT OF THE DEATH PENALTY 355 (2018) (“At a research university, why would students not be learning research? At one of the nation's best public universities, why would a professor not engage these brilliant 


\section{A. Objectives of the Study}

This study has five aims:

1. To identify in each case, from archival data, some of the recognized causes of false conviction error: Did it involve racial profiling; false eyewitness misidentification, invalidated forensic science, false confessions, immaturity of interrogation suspect; government misconduct, snitches, and bad lawyering; tunnel vision by investigators.

2. To identify in each case, from archival data, the root sociological causes of false conviction error: Did it involve racial bias, justice system culture, the adversary system, plea bargaining, behavior of immature accused, stop and frisk policies, media, and the American punitive wars on drugs and crime.

3. To examine, through structured interviews of criminal justice professionals and peer student interviews, actual information about the case, general information about the criminal justice system, and public opinion information about wrongful convictions.

4. To generalize, from the information collected in individual exoneration cases and structured interviews, the enduring structural and sociological problems common to wrongful conviction error.

5. To identify and anticipate possible structural conditions which give rise to wrongful convictions in future cases, and to make recommendations for reforms, better training, and compensation for exonerees which may prevent future or hidden injustices.

minds into the world of research and social impact? We hope this book will be a model for that."); Leona Jochnowitz, Book Review, 55 CRIM. L. BULL. 1107, n. 59 (2019). 


\section{B. Design, Data, and Sample}

This study derives its data from two unique sources. First, we obtained archival data from The Innocence Project and the Innocence Record, through a unique collaboration between Winston \& Strawn LLP and the Innocence Project which collected documents on DNA exoneration cases. ${ }^{73}$ Second, we interviewed public officials in person or by telephone. ${ }^{74}$

The Innocence Record database, which is accessible to researchers by permission, covers 351 exoneration cases and provides trial transcripts and court documents in 234 of the cases. The subjects are cases of actual exonerees - persons who have been exonerated following their wrongful convictions and arrests in the criminal justice system. The archival sources in the database of the Innocence Record

73 THE INNOCENCE RECORD, https://www.innocencerecord.org/ (last visited Jan. 18, 2021). The law firm of Winston \& Strawn LLP collaborated with the Innocence Project which has directly or indirectly been involved in the vast majority of the cases contained within the Innocent Record. This document database and website are the products of a unique collaboration between Winston \& Strawn LLP and The Innocence Project. The public records and court files were gathered through the cooperation and perseverance of more than 700 volunteers, including attorneys, court personnel, paralegals, and law students. Once obtained, the files were then digitally imaged and carefully reviewed for key data by attorneys and summer associates of Winston \& Strawn. This data was then input into a searchable database that can be engaged in numerous ways. Id. The circumstances of each exoneree's wrongful conviction is profiled on the site, along with information concerning the court proceedings and participants. Access to the trial transcripts requires that the researcher be approved by Winston \& Strawn, complete a confidentiality agreement, and obtain Institutional Review Board approval to conduct research. The confidentiality agreement allows the researchers to contact expert witnesses and public officials, but not victims. Under the Innocence Record Data Protection Plan (April 26, 2016), described below, professional witnesses in the archival documents may be contacted. The interviews conducted in this study involved public officials. The transcripts are not available to the general public through this site. Dr. Jochnowitz is the principal researcher in this study. She disseminated the trial transcripts cited herein to the researching students. Readers may contact Dr. Jochnowitz if they have specific questions regarding the transcripts cited herein. For Winston Strawn's methodology in coding and organizing the trial transcripts, see Methodology for Creating and Preparing Case Abstracts, INNOCENCE RECORD, https://www.innocencerecord.org/Pages/OurPartnership.aspx; see also Exoneree Case Abstracts: Terms and Definitions, INNOCENCE RECORD, https://www.innocencerecord.org/AdministrativeDocuments/InnocenceRecordTer msAndDefinitions.pdf.

${ }^{74}$ In some cases, students also conducted interviews of peers and focus groups which showed attitudes among fellow students and community members. 
include trial transcripts, trial testimony from publicly available trial transcripts, sentencing, charges, exonerations, eyewitnesses, confessions, self-incrimination, defendant testimony from public trials, and forensic evidence. Students coded several archival and trial documents for seventeen cases in the sample. The coding of original trial transcripts provides information which may not have been provided by the media and shows what the jury heard in order to reach a wrongful conviction verdict. A follow-up study, which is the subject of a future publication, was conducted with graduating students at Curry College in Boston, in 2019, many of whom worked as Boston City Police Officers. The officers added their practical expertise and their appreciation of structural problems like justice system culture.

Institutional Review Board (IRB) approval was obtained by all participants through the Hartwick College, Northern Vermont University (NVU, Johnson campus), and Curry College IRB. ${ }^{75}$ Protections required by the Innocence Record include that names of crime victims and witnesses that are discovered through this resource will not be used or contacted with the exception of public officials and experts. $^{76}$

\section{The Cases}

The sample cases were selected in order to provide for exonerees of diverse race and ethnicity, females, juveniles, intellectually disabled persons, and death penalty cases. Females and juveniles are exceptionally underrepresented in the database, as well as the criminal justice system, but their stories are an important part of the study. In addition, cases were selected from the published literature on wrongful convictions and media. The documents which were

${ }^{75}$ All the students completed IRB-related training, and the interviewees who are public officials knew and gave consent to being identified and quoted. They also will be informed about their remarks being used even if exempt from formal confidentiality requirements. In addition, there were inter-rater reliability checks, with several students assigned to coding the transcripts and doing interviews.

76 THE INNOCENCE RECORD, supra note 73. Witnesses who testified in their professional capacity (e.g., attorneys, police officers, laboratory analysts, experts, etc.) are not subject to the same protections and may be contacted. Only Dr. Jochnowitz and a teaching assistant were given full access to the exoneration case transcripts in the Innocence Record, and the archival materials were disseminated to students for coding. Access to the trial transcripts and archival documents are available to researchers by agreement under the Innocence Record Data Protection Plan Form. 
systematically studied include trial transcripts, clemency petitions (Earl Washington), ${ }^{77}$ witness and defendant trial testimony, sentencing documents, charging instruments, arrest records, police interrogations, confessions, clemency documents, briefs, and forensic evidence. It is neither feasible nor scientifically sound to randomly select the cases. Some of the cases do not contain full files or trial transcripts. The selection of cases was based on the quality and completeness of the archival data file and the demographic representativeness of the exonerees.

The seventeen cases include the Central Park Five exonerees and some death row cases:

- Kevin Richardson, Antron McCray, Raymond Santana, Yusef Salaam, and Kharey Wise ${ }^{78}$

- Kenneth Adams and Paula Gray ${ }^{79}$

- Kirk Bloodsworth ${ }^{80}$

- Jimmy Ray Bromgard ${ }^{81}$

- Larry Youngblood ${ }^{82}$

- Jeff Deskovic ${ }^{83}$

${ }^{77}$ Eric M. Freedman, Earl Washington's Ordeal, 29 HofsTRA L. REV. 1089, 1095, 1105 (2001).

${ }^{78}$ April 19, 1989; Central Park Five cases (New York City, New York); False confessions by teens; Black and Hispanic defendants.

${ }^{79}$ May 11, 1978; Ford Heights Four (Chicago, Illinois); Charged with abducting, gang-raping, and murdering a recently engaged couple from a filling station. Bodies found in East Chicago Heights; Black male and female defendants. Paula Gray is a rare female exoneree in the sample. Her arrest involved a coerced confession. Black defendants.

${ }^{80}$ June 25, 1984 (Maryland); Accused of the beating, sexual assault, and murder of a nine-year old girl. White defendant. Twenty-two-year-old Bloodsworth, a former marine, was the first person exonerated from death row. He was falsely identified by child witnesses after an anonymous tip and then a TV broadcast of his photo.

${ }^{81}$ March 20, 1987 (Montana); White defendant; Accused of the rape of an eightyear-old girl; child victim eyewitness identification.

${ }_{82}$ October 29, 1983 (Arizona); Black defendant; Ten-year-old Hispanic victim was abducted from a carnival and was molested and sodomized. Child victim erroneously identified him.

${ }^{83}$ November 15, 1989 (Long Island, New York); White defendant. Teen accused of rape and murder of a fifteen-year-old female classmate. Coercive police interrogation and false confession. 
- Larry Ollins, Calvin Ollins, Omar Saunders, and Marcellius Bradford $^{84}$

- Earl Washington ${ }^{85}$

- Ronald Cotton ${ }^{86}$

The archival transcripts in the Innocence Record database were qualitatively coded to collect information regarding the demographics of the accused, the type of case, the type of evidence presented, and the possible reasons for the wrongful convictions. ${ }^{87}$

\section{Structured Interviews with Professionals, Law Enforcement Witnesses, and Student Peers}

Structured Interviews with professional witnesses and student peers were conducted for the purpose of identifying public attitudes about wrongful convictions and to question available persons involved

${ }^{84}$ October 18, 1986 (Chicago, Illinois); Black youth defendants; Accused in the murder and rape of a twenty-three-year-old medical student Lori Roscetti. Coercive interrogations and confessions, false forensic evidence.

${ }^{85}$ June 4, 1982 (Culpepper, Virginia); Black intellectually disabled defendant. Accused of the murder and rape of a White victim; false confession. Clemency and got a stay within days of execution. It took seventeen more years to get him out of prison.

${ }^{86}$ June 29, 1984 (North Carolina); Black Defendant; Accused of B/W rape of Jennifer Thompson; cross racial victim misidentification.

${ }^{87}$ Demographic Information: Date of arrest, first trial; Date of exoneration; Race of Accused; Gender of Accused; Date of Birth and Age of Accused at time of crime; Race of Victim; Gender of Victim; Age of Victim at time of crime

Type of Case: Charges; Type of Document; Trial transcripts, trial testimony; Sentencing, charges, exonerations, eyewitnesses, confessions, self- incrimination, defendant testimony, forensic evidence.

Types of Evidence: Eyewitness testimony; Snitch testimony; Defense witnessesAlibi; Family; Character; Teachers; Expert witness testimony regarding mental issues and intellectual disability; Psychiatrist, psychologist, medical doctor; Expert testimony regarding forensic evidence; Defendant's own testimony; Confessions to Police; Compromising statements to police; Police interrogations; Prosecutor Arguments; Defense Lawyer Arguments and Failings

Reasons for Wrongful Conviction: Eyewitness misidentification, invalidated forensic science, false confessions, government misconduct, snitches, and bad lawyering. Racial profiling? False eyewitness ID? False confession? Immaturity of the accused? Poor investigation? Tunnel vision by investigators? Root sociological causes of conviction error; Racism, justice system culture, the adversary system, plea bargaining, behavior of immature accused, and the American punitive wars on drugs and crime. 
in the case. Under the Innocence Record Data Protection Plan, professional witnesses in the archival documents may be contacted. ${ }^{88}$

Structured or phone interviews were conducted with public officers, elected officials, judges, prosecutors, defense lawyers, researchers, and investigators, some of whom were officially involved with the case and others who were members of the community. The purpose of the interviews was to collect actual information about the case, general information about the criminal justice system, and public opinion information about wrongful convictions. ${ }^{89}$

To conduct the interviews, students also designed a vignette of their case and asked the participants a series of open-ended questions regarding their particular case and/or their attitudes about wrongful convictions, which the students recorded. Some of the following questions included: When did you realize that the subject might be wrongfully convicted? What information led you to this conclusion? How was this information provided? Did you take any specific action after you realized the subject may have been wrongful arrested or convicted? What do you think was the reason for this wrongful conviction?

The interviewees were selected based on the information in the trial transcripts, literature and media which identifies important persons. Contacts were also found on exoneration websites, like the Deskovic Foundation. ${ }^{90}$

${ }^{88}$ THE INNOCENCE RECORD, supra note 73. Names of crime victims and witnesses that are discovered through this resource will not be used or documented in any way, nor will any attempt to contact them be made, with the following exception. Witnesses who testified in their professional capacity (e.g., attorneys, police officers, laboratory analysts, experts, etc.) are not subject to the same protections and may be contacted. (Innocence Record Data Protection Plan Form, April 21, 2016). This exception forms the basis of student interviews.

${ }^{89}$ Another purpose of the interviews was to teach students qualitative interview methods and ethical principles in research interviews. Students received IRB certification to conduct these interviews.

${ }^{90}$ DESKOVIC Foundation, https://www.deskovicfoundation.org (last visited Jan. 19, 2021). 


\title{
IV. FINDINGS
}

\section{A. Archival Data}

\author{
i. $\quad$ The People of the State of Illinois v. Larry \\ Ollins $(1988)^{91}$
}

On the night of October 18, 1986, medical student Lori Roscetti was returning to her home on Chicago's West Side after a late-night study session, when near the corner of her home, she was abducted at knifepoint by several men. ${ }^{92}$ Roscetti was driven to a remote location where she was brutally raped and beaten over the head with a concrete block. ${ }^{93}$ Her body was found the next morning. ${ }^{94}$ After working the case for months without any good leads, detectives were under enormous pressure to make an arrest and were willing to go to any lengths to do so. ${ }^{95}$ A large reward, multiple interviews with the threat

${ }^{91}$ Larry Ollins, INNOCENCE PROJECT, https://www.innocenceproject.org/cases/larryollins (last visited Apr. 18, 2020); Jon B. Gould et al., Predicting Erroneous Convictions: A Social Science Approach to Miscarriages of Justice Document, NCJRS (Feb. 2013), https://www.ncjrs.gov/pdffiles1/nij/grants/241389.pdf; Maurice Possley \& Steve Mills, New Evidence Stirs Doubt Over Murder Convictions, $\quad$ CHI. $\quad$ TRIB. $\quad$ (May 2, 2001) http://www.chicagotribune.com/news/watchdog/chi-010502roscetti-story.html;

Shane DuBow, Perfect Evidence, THIS AM. LIFE (Apr. 19, 2002), https://www.thisamericanlife.org/210/perfect-evidence. This case was coded and analyzed by NVU, Johnson campus students, Tonya Kendall (with Fadhili Achinda). Court Transcripts were obtained from the Innocence Project, Innocence Record: OLL-000447; OLL-000718; OLL-000828. Secondary materials were also accessed. 92 See Larry Ollins, NoRE (May 6, 2014), https://www.law.umich.edu/special/exoneration/Pages/casedetail.aspx ?caseid=3446 ; Possley \& Mills, supra note 91.

${ }^{93}$ Ollins v. O'Brien, No. 03-C-5795, 2006 WL 1519286 (N.D. Ill. May 26, 2006); Ollins v. O'Brien, No. 03-C-5795, 2005 WL 730987, at*1 (N.D. Ill. Mar. 28, 2005) ("Ollins and Saunders were found guilty of the murder and sexual assault of Roscetti. ... Bradford pleaded guilty to aggravated kidnapping. All three Plaintiffs served time in prison for the crime. Evidence gained from the initial investigation was subjected to DNA analysis in 2001. Analysis of this evidence suggested that none of the original four defendants were involved in the rape or murder of Lori Roscetti. The Honorable Dennis Porter vacated the convictions of all four original defendants on December 5, 2001. On October 17, 2002, Governor George Ryan pardoned Calvin Ollins, Larry Ollins, Marcellius Bradford, and Omar Saunders based on their innocence.").

${ }^{94}$ DuBow, supra note 91.

${ }^{95}$ As evidenced by the coded transcripts. 
of arrest, and coercion tactics led to the confessions of Marcellius Bradford and Calvin Ollins and the convictions of Larry Ollins and Omar Saunders. ${ }^{96}$ All four men were factually innocent and exonerated by DNA evidence. ${ }^{97}$

Trial transcripts in the Ollins case show how numerous factors culminated and engender the conviction of innocent persons. This case has an intermingling of routine and structural flaws consisting of racial profiling, false testimony, coerced confession, incentivized testimony, poor investigation, poor forensic hair analysis, tunnel vision, and the adversarial system. The root sociological causes of the conviction error included racism, justice system culture, plea bargaining, snitch testimony, and the adversarial system. The transcripts showed subtle themes not always captured in the media, such as how a phone call to a police profiler ${ }^{98}$ spurred law enforcement's tunnel vision and the creation of a suspect list driven by racial profiling, which led to a poor investigation by the detectives in charge (e.g. coercion tactics, false narrative, and weak forensic hair analysis). And when all else failed, investigators used forced false confessions and snitch testimony to seal their case. Further, the trial consisted of false forensic testimony by a forensic analyst within the State's crime lab, with the work culture that they were "prosecution team players." 99 There was no credible evidence against the teens. Yet the prosecutor still brought charges against two of the four defendants. This kind of prosecutorial decisionmaking is evidence of a breakdown of "justice" in our adversarial system.

${ }^{96}$ Trial Tr. OLL-000718; Trial Tr. OLL-000828.

${ }^{97}$ INNOCENCE PROJECT, supra note 24.

${ }^{98}$ Robert K. Ressler \& Tom Shachtman, Whoever Fights Monsters: My Twenty Years Tracking Serial Killers For the FBI 185 (1992). Dr. James Cavanaugh, medical director of the Isaac Ray Center of Rush-Presbyterian St. Luke's Medical Center and former instructor of Lori Roscetti called his former colleague Robert Ressler, FBI police profiler regarding Roscetti's murder. A formal request for help with the investigation came from Tom Cronin, a Chicago police officer who was a former student of the profiler when he attended the FBI Academy. Id.

${ }^{99}$ Steve Mills et al., When Labs Falter, Defendants Pay, CHI. TRIB. (Oct. 20, 2004), https://www.chicagotribune.com/investigations/chi-041020forensics-story.html ("Many forensic scientists at the state police labs ... saw their role as members of the state's attorney's team. 'They thought they were prosecution witnesses,' . . . . 'They didn't understand they were just scientists.'”). This is a quote from Don Plautz, former director of the Illinois State Crime Lab. Pamela Fish, who testified against Ollins and Saunders, worked for the Illinois State Crime Lab. Id. 


\section{Tunnel Vision}

Tunnel vision does not arise from one small decision of law enforcement but from actions arising from "escalating commitments . . . [resulting in] incremental descent into poor judgment." 100 The coded transcripts in this case reveal that after months of investigation with no leads, investigators developed a list of factors ${ }^{101}$ to guide their investigation based on information they received from Robert Ressler, FBI profiler. ${ }^{102}$ Investigators were convinced that a young black man had committed the rape and murder of Roscetti and focused their attention on the ABLA housing projects, resident to approximately 350 black teens. ${ }^{103}$ They made a list of ninety-two suspects, all young black men from the ABLA housing project, questioning twenty. ${ }^{104}$

\section{Poor Investigation}

Detectives continued to focus on their named suspects, namely Larry Ollins, Marcellius Bradford, and Omar Saunders, even though

${ }^{100}$ Elizabeth Webster \& Jody Miller, Gendering and Racing Wrongful Conviction: Intersectionality, "Normal Crimes," and Women's Experiences of Miscarriage of Justice, 78 ALB. L. REV. 973, 1027 (2015) (quoting William S. Lofquist, Whodunit? An Examination of the Production of Wrongful Convictions, in WRONGLY Convicted: Perspectives On FAILED Justice 174, 176 (Saundra D. Westervelt \& John A. Humphrey eds., 2001) [hereinafter WRONGLY CONVICTED]).

${ }^{101}$ Trial Tr. OLL-000745-48. Four factors listed in the trial transcripts that guided investigators' suspect list are:

1. That it must be someone who was familiar with the access road to the railroad tracks at Loomis;

2. Someone who had been arrested in that area before;

3. That the suspect would match the hair found on Roscetti's auto seat. A hair that the crime lab concluded had characteristics that correspond with a large percentage of Blacks;

4. The person that was seen at 15 th and Loomis at $4: 30$ or $4: 40$ a.m. was a young black person. Id.

102 Trial Tr. OLL-000744.; see RESSLER \& SHACTMAN, supra note 98, at 187; Possley \& Mills, supra note 91 (according to Ressler, he told the police to look for a group of "black youths, somewhere between three and six males, ranging in age from 15 to 20 , who would have previously been in jail and who lived close by the scene of the abduction and the railroad trestle where Roscetti had been killed").

103 Trial Tr. No. OLL-000746.

104 Trial Tr. No. OLL-000745. 
the forensic evidence was not consistent with any of the young men. ${ }^{105}$ Court transcripts revealed that five fingerprints ${ }^{106}$ found at the scene of the crime, none of which belonged to Larry Ollins, Calvin Ollins, Marcellius Bradford, and Omar Saunders. The fingerprint analyst was not called to testify; rather, the trial transcript noted a Court stipulation to this effect. ${ }^{107}$ Moreover, at best, hair analysis found there was only a seventy-six percent probability that the hair found at the crime scene came from an African American. The value and reliability of forensic microscopic hair comparison based on serological methods has been overstated. ${ }^{108}$ Further, that the hair could have come from another source. During a sidebar, the parties stipulated that Rosetti's roommate had an African American friend that had been to the apartment less than three weeks before the murder. ${ }^{109}$

105 See Dianne L. Martin, Lessons about Justice from the "Laboratory" of Wrongful Convictions: Tunnel Vision, the Construction of Guilt and Informer Evidence, 70 UMKC L. REV. 847, 848 (2002) (noting that a by-product of tunnel vision is when an investigator ignores evidence that points away from guilt).

106 Trial Tr. OLL-000541-45 (five ridge impressions were found on the exterior of the car - Two of the fingerprints that were recovered from the exterior of the car were on the driver's side front door and one was near the driver's side rear door, both near the door handle; one ridge impression and one latent print near the left rear door (passenger side); one ridge print found on interior passenger door window.).

107 Trial Tr. OLL-000911 ("It is stipulated between the state and the defense that comparing the ridge impressions found inside and outside of Lori Roscetti's car Chicago Police Officer Thomas Krupowitz of the crime lab latent fingerprint comparison unit would testify that . . . compared to Larry Ohms Calvin Ollins Marcellius Bradford and Omar Saunders fingerprints . . . there was no match.”).

108 See Henry C. Lee \& Elaine M. Pagliaro, Is Hair Reliable Forensic Evidence?, 1 J. FoRENSIC PATHOLOGY 1, 1 (2016).

109 Trial Tr. OLL-000923.

Defense: "You can't qualify how many people a particular hair came from? I mean, how many it could have come from?"

Bisbing: "No, not with any kind of accuracy" (Trial Tr. OLL-000909).

The Court stipulates that Roscetti's roommate would testify to a black friend sleeping on their sofa:

Judge: It is stipulated by and between the parties that if Christine Gorman were to testify, she would testify as follows ... that in August of 1985, Lori Roscetti introduced Christine Gorman to a high school friend from Springfield, Illinois, named Calvin Barnes. Christine Gorman would describe Barnes as follows. Male black, twenty-five years of age, six feet tall, 250 pounds, dark complexion, with curly dark brown hair and brown eyes. That from August 1985, until September 1986, Calvin Barnes visited our apartment three or four times. On one occasion, Barnes stayed overnight. He slept on the living room couch. To my knowledge, there was no romantic relationship between the parties. That Barnes last visited 


\section{ii. Deceptive and Coercive Interrogation Practices}

Police used deceptive and coercive interrogation practices to interview juveniles Larry and Calvin Ollins, Omar Saunders, and Marcellius Bradford, and facilitating in them blaming each other. ${ }^{110}$ They brought in Larry Ollins who had a juvenile record as a petty thief. He was one of the teens that detectives questioned regarding the crime. However, after several hours of interrogation, Larry stuck by his innocence, telling the police that he did not know anything about a murder. Detectives allowed Ollins to go home, but his refusal to buckle to the pressure and confess did not do him any good because he would soon be re-arrested. However, trial transcripts indicate that detectives felt comfortable that Ollins did not have anything to do with the crime at the time they allowed him to go home. ${ }^{111}$ Police continued to fish around trying to find someone to confess and arrested several people in connection with the crime. Gilty was arrested prior to Ollins or Bradford. The police brought in Bradford based on what they were told by Gilty. ${ }^{112}$

\footnotetext{
Lori Roscetti at our apartment approximately three weeks before October $18^{\text {th }}, 1986$.

Id.

110 See Trial Tr. OLL-000751; Ollins, 2006 WL 1519286, at *3.

111 Trial Tr. OLL-000751.

Defense: You read the information that was amassed in. the course of this investigation throughout the investigation? You talked with the crime laboratory, did you? (OLL-000750) [h]e had the equipment to analyze har and determine their elemental composition....[A] and based on all the information you had and all the investigations that were done.... [y]ou released Larry Ollins, did you not?

Detective: Yes.

Defense: And it wasn't until after you talked with Marcellius Bradford that you went out to re-arrest Larry Ollins, correct?

Detective: Correct.

Id.; see Tepfer, supra note 62.

112 Trial Tr. OLL-000873 (see information regarding Anthony Guilty under "Snitch testimony"). Investigators also used interrogation tactics with Gilty:

Gilty: They were talking to me. They handcuffed me to a ring there, you know, coming out of the wall and they told me I couldn't sit down, you know.

Defense: When you said you were handcuffed; did you say that was to a ring?

Gilty: Yeah, a little iron piece coming out of the wall.

Trial Tr. OLL-000873.
} 


\section{iii. $\quad$ False Confession: Marcellius Bradford (Co- Defendant)}

Interrogators used many different tactics to elicit statements from suspects. ${ }^{113}$ Court transcripts show how after his twenty-fourhour mentally and physically coercive interrogation, ${ }^{114}$ Marcellius Bradford told police that he, along with Larry Ollins and his fourteenyear-old mentally challenged cousin, Calvin Ollins, committed this crime. ${ }^{115}$

Marcellius Bradford recalled how he was treated during questioning:

"They handcuffed me to this ring. . . Every time the door opened, it seemed like somebody [would] come in there and beat me," he said. "I'm tired, sleepy, hungry, can't use the bathroom. They give me a can to use for the bathroom. They sit down--'Tell me what happened, how you killed her.' Kill who? I said. 'You know who,' they said."116

Prior to implicating himself and the other defendants, the trial transcripts reveal testimony that Bradford falsely gave police several names of people allegedly involved in the murder. ${ }^{117} \mathrm{He}$ also went into

${ }^{113}$ NORRIS ET AL., supra note 6, at 63.

114 Trial Tr. OLL-000770.

Defense: You had Marcellius Bradford there since 1:30 the previous day? Detective: That's right.

Defense: And he had been with you from 9:30 until 5:00 a.m. the next morning, and you hadn't contacted the State's Attorney's Office?

Defense: And that's when Ms. Sussman, the State's Attorney, came to Area 4?

Detective: 5:00 o clock we contacted them.

Detective: Yes.

Id.

115 Ollins v. O’Brien, No. 03-C-5795, 2005 WL 730987, at *1 (N.D. Ill. Mar. 28, 2005); Possley \& Mills, supra note 91 ("[Bradford] said he falsely implicated himself and the others because police beat him during his interrogation--a claim his family also made just after his arrest when they said they saw him bruised.").

116 Possley \& Mills, supra note 91.

117 Trial Tr. OLL-000753-54

Defense: He told you at one point about an Emmett being involved in this crime....[A]nd he told you about a person by the name of Grease being involved in this case, isn't that right?

Detective: That's right. 
great detail about how some of these people committed the crime. ${ }^{118}$ When Bradford admitted to lying to the police, ${ }^{119}$ trial transcripts indicate that detectives created a false narrative, telling Bradford that Ollins implicated him in the crime. ${ }^{120}$ Moreover, investigators fed him the details of his confession. Bradford claimed:

\footnotetext{
Defense: At one point he had a conversation with an officer by the name of Geraghty....

Detective: Yes.

Defense: And then later on he said that a person by the name of Daniel was involved in this crime....

Detective: Yes, he did.

Id.

${ }^{118} I d$.

Defense: ...[A]nd that he told Officer Geraghty that Emmett and Grease had taken, in his words, I think it was, a blonde up on the tracks....that the next day they sold a socket wrench set....

Detective: That's right.

Defense: ....[A]nd he said that Daniel at one point got out of the car....[I]n fact, he told that to the State's Attorney of Cook County, did he not?

Detective: Yes, he did.

Defense: And he gave great detail about what Daniel had done and how Daniel was involved in this murder, isn't that right?....[A]nd he signed a statement....[A]nd he said it was the truth, isn't that correct?

Detective: Yes.

Id.

${ }^{119} I d$.

${ }^{120} \mathrm{Id}$. at 766 .

Defense: Sir, I'm asking you if you confronted Marcellius Bradford with the fact that Larry Ollins said that he, Bradford, was involved in the murder of Lori Roscetti?

Detective Mercurio: What I told him was that someone told us that.

Defense: That Larry Ollins said....

Detective Mercurio: That Larry Ollins said that him and Bradford were involved?

Detective Mercurio: What I told him was that someone told us that.

Defense: That Larry Ollins said....

Detective Mercurio: That Larry Ollins said that him and Bradford were involved?

Defense: And you confronted him with that before he ever mention the name of Larry Ollins in connection with this case, isn't that right? Detective Mercurio: That's right.

Id.
} 
"They tell me to read this over for a couple of hours and we'll be back," Bradford said in the interview. "I'm reading this paper and it didn't make no sense. Wouldn't nobody believe I said these things. It was a statement, handwritten... . They told me, 'We want you to study this and there's a lady [an assistant state's attorney] who's going to come in here and we want you to tell her that you did this. We're going to let you go home then."'121

This claim was further substantiated by Dr. Richard Ofshe, who has researched and published extensively on the subject of false confession. In an affidavit to the Court on behalf of the defendants, Dr. Ofshe states:

Remarkably the crime story told in the confession of Mr. Ollins and Mr. Bradford matches the scenario invented by Mr. Ressler too well for the similarity to be accepted without closer scrutiny. One possible way to describe the match between the profile and the confessions is that Mr. Ressler is simply such an astute profiler that he got everything correct and that the police obtained voluntary and reliable confessions. Another possibility is that the police coerced confessions that matched Mr. Ressler's scenario from two young men who may have had no involvement in the crime. ${ }^{122}$

Thus, the crime story told in the confession of Mr. Ollins and Mr. Bradford matches the scenario invented by Mr. Ressler. This suggests the police coerced confessions that matched Mr. Ressler's scenario from two young innocent men.

\section{iv. False Forensic Testimony}

The following quotes from the coded transcripts show false testimony by State expert witness Pamela Fish. Fish was responsible for at least four other exonerations where her testimony was

\footnotetext{
${ }^{121}$ Possley \& Mills, supra note 91.

122 Trial Tr. SAI-000178.
} 
false/misleading. ${ }^{123}$ She testified that she could not rule out Ollins as one who left the semen at the crime, ${ }^{124}$ although, it was not possible for the semen to have been his because he was not a secretor. ${ }^{125}$

Then Fish discusses another type of testing that has nothing to do with secretor/non-secretor status which is the PGM subtyping classification. This is very technical testimony that very likely confused the jury. ${ }^{126}$

123 See Rob Warden, Dana Holland, NAT'L REgistry of EXONERATIONS, https://www.law.umich.edu/special/exoneration/Pages/casedetail.aspx?caseid=3301 (last visited Oct. 25, 2020) (according to the National Registry of Exonerations, Fish was implicated in the false forensic testimony in the case of Dana Holland and in several other cased including the Ollins' cases); see also Steve Mills, Controversial Ex-Forensic Lab Analyst Focus of Another Inmate's Appeal, CHI. TRIB. (Jan. 31, 2017), https://www.chicagotribune.com/news/ct-pamela-fish-murder-case-appealmet-20170129-story.html?outputType=amp.

${ }^{124}$ Trial Tr. OLL-000599.

Defense: Now, is it not correct that someone that was a secretor deposited semen in Lori Roscetti?

Fish: That's correct.

Defense: So, it's correct, is it not, that someone other than the defendant, Larry Ollins, deposited semen in Lori Roscetti?

Fish: It's a possibility, yes, sir.

Defense: Now, you have told us that you cannot determine how many people deposited the semen in Lori Roscetti, is that correct?

Fish: That's correct.

Defense: It is entirely consistent with all of your testing that someone other than Larry Ollins, without Larry Ollins, deposited semen in Lori Roscetti, is it not?

Fish: No, sir, it is not.

Id.

${ }^{125}$ Trial Tr. OLL-000598 ("Defense: And did you make certain observations or conclusions as to this blood and his saliva concerning his secretor status? Fish: From the blood cells that I received or tested from Larry Ollins, I determined that he was a non-secretor.").

126 Trial Tr. OLL-000601-12. Larry is a non-secretor. Larry is the only one that could have left the minus one. Yet, the person who deposited the semen was a secretor with a minus one.

Defense: "Of the four persons arrested in the Lori Roscetti case whose blood you received - Marcellius Bradford's, Calvin Ollins', Omar Saunders' and Larry Ollins - in their PGM subtype, how many of their PGM subtypes have a minus one?"

Fish: "Only one of the individuals does"

Defense: "Who is that?"

Fish: "Larry Ollins"

Defense: "In the vaginal swab that you had, was there a minus one?" 


\section{v. Racial Profiling}

The trial transcripts show how race was the underlying motivating factor in who became a suspect, when the lead detective answered, "Yes" to the following questions by the defense:

Defense: The suspect list that you made up in large part revolved around the fact that you concluded that it was a black teenager or a group of black teenagers that committed this crime, isn't that correct?

Defense: And many of them lived in the ABLA housing project? ... [I]n fact, you concluded that most of them lived in the ALBA housing project, isn't that right?

Defense: And you concluded that most of them were young black teenagers, isn't that right?

Defense: And many of them lived in the ABLA housing project? ... [I]n fact, you concluded that most of them lived in the ALBA housing project, isn't that right?

Defense: And you concluded that most of them were young black teenagers, isn't that right?

Defense: You finally concluded ... that the person that was seen at $15^{\text {th }}$ and Loomis at 4:30 or 4:40 a.m. was a young black person, is that correct? ${ }^{127}$

Further, transcript coding found that the detectives had determined that a hair found at the crime scene belonged to a black man which bolstered their belief that one of the teens that resided at the ALBA housing project was the culprit. ${ }^{128}$

Fish: "Yes, sir, there was"

Defense: "Of those four individuals, which of them could account for that minus one?"

Fish: "Larry Ollins"

Id.

127 Trial Tr. OLL-000744-47.

128 Trial Tr. OLL-000748.

Defense: The third factor you considered was that hair was recovered and it was your conclusion, or the conclusion of the crime laboratory - hair recovered from the seat of the victim's auto ... [y]ou concluded that came from a black person. ... Well, they concluded that it was $76 \%$ likely that it was a black person, is that correct

Detective Mercurio: They said a large percentage of people that have characteristics with that type of hair are black. 


\section{vi. $\quad$ Plea Bargaining}

According to Possley and Mills, "Bradford said he agreed to testify against Larry Ollins in return for a reduced prison term." 129 Coding of the transcript revealed where Bradford testified to this same effect. ${ }^{130}$

The intellectually disabled Calvin Ollins was questioned and was told that his cousin was accusing him of taking part in this crime. They told Calvin that if he would say that Larry took part in the crime, he would be able to go home. Calvin complied with police authority and was in custody for the next fifteen years. ${ }^{131}$ Intellectually disabled persons often try to placate persons in authority by telling them what they want to hear, as in the case of Earl Washington discussed below. ${ }^{132}$

A month later, in February 1987, police picked up Omar Saunders and began advising him what to say, in a blatant display of misconduct. Detectives told Saunders to say that he was breaking into railroad cars and heard the screams of the victim. He was then told to say that when he came upon the scene, he saw, "four black guys and a white broad." 133 Because Saunders refused to say any of that, he was

Defense: And you based upon those facts you believed, and you focused your investigation on young black teenagers who lived in the ABLA housing project?

Detective Mercurio: There are other factors, but that's most of it.

Id.

${ }^{129}$ Possley \& Mills, supra note 91 . Possley and Mills are reporters from the Chicago Tribune.

${ }^{130}$ Trial Tr. OLL-000456.

Defense: "You know that you have to testify against Larry Ollins and then the State is going to dismiss the murder charge against you, isn't that right?

Marcellius Bradford: "Yes"

Defense: "And you understand that the sentence you are to receive, the sentence that the State is going to recommend is 12 years in the penitentiary, and you know that under our system of law, you will receive day-for-day credit, don't you?"

Marcellius Bradford: "Yes."

Id.

131 Trial Tr. OLL-000154-65; DuBow, supra note 91.

132 Freedman, supra note 77 at 1095.

133 Trial Tr. OLL-000456. 
subsequently arrested for the same crimes and spent the next fifteen years of his life behind bars. ${ }^{134}$

\section{vii. $\quad$ Snitch Testimony}

Incentivized snitch testimony is a significant cause of wrongful convictions. Innocence Project Data indicates that informants were involved in $17 \%$ (55) of 325 exonerees. ${ }^{135}$ Snitches are found in the data base of convictions in the National Registry of Exonerations under perjury, or $7 \%$ of $56 \% .{ }^{136}$ When investigators were still at a dead end, they used incentivized witness Anthony Gilty to testify against Larry Ollins by threatening to charge him with the crime. The following quotes from the coded transcripts indicate that Anthony Gilty engaged in Snitch testimony. ${ }^{137}$

Defense: Were you told that you could be charged with conspiracy to commit this crime?

Anthony Gilty testified in front of a grand jury that Larry Ollins had told him that he and the others committed this crime. On the stand, he denied that Larry Ollins told him that he committed this crime, only that they were talking about the reward offered in the crime. ${ }^{138}$

\footnotetext{
${ }^{134}$ Id.; DuBow, supra note 91.

${ }^{135}$ DNA Exonerations in the United States, supra note 27.

136 NORRIS ET AL., supra note 6 at 106.

137 Trial Tr. OLL-000873-74.
}

Defense: What did you say to the police?

Gilty: I say we just had a conversation only about the reward posters. And they kept saying, thank you, and they named off a bunch of names. They said you all was the wildest ones in the area, so you all had to do it.

Defense: Were you told that you could be charged with conspiracy to commit this crime?

Gilty: Yes, and concealment ... [T] hey telling me, you know, that they were going to charge me with it, and pointing at me, things like that there..... [T] hey were twisting my words, making it like I really said something when I didn't.

Id.

138 Trial Tr. OLL-000876. "Prosecutor: During that conversation did Larry Ollins make any statements to you about Lori Roscetti, the girl that was killed on the tracks? Gilty: No....[H]e ain't told me he killed her." Id. at 876-77 (The prosecutor noted during a sidebar that he was fairly shocked that Gilty said Ollins did not admit to doing the crime. He gave no explanation to why he lied. He denied that he was offered a plea bargain. He did testify that the police were trying to implicate him. It was alluded to by the defense that the motive could have been the reward.). 


\section{viii. Justice System Culture}

According to Omar Saunders, "The policeman was white, victim was white. The judge was white. The prosecuting attorney was white. Everybody was white that done this." 139

\section{ix. Adversarial System}

When our adversary system is a cause in a wrongful conviction, it means that "some of the reasons we convict the innocent flow from the choices we have made as a society about the process we use to determine guilt." 140 Prosecutors are supposed to be capable of rising above their roles as advocates to assure that justice is done. ${ }^{141}$ A large part of that commitment entails not bringing forth a case unless the evidence shows "serious grounds to believe that person is guilty." 142 Even if the police err in the assumption that a person will not be arrested unless there are serious grounds to believe that person is guilty, "we assume that prosecutors will exercise their discretion in not proceeding with formal charges when the accused is perceived as probably innocent." 143 The prosecution knew all along that these young men were not guilty and that the forensic evidence was unreliable. He wanted a conviction to show that they had solved this crime. There was no fingerprint evidence, no blood evidence, no eyewitness evidence, and the false confessions, were coerced.

\section{x. $\quad$ Conclusion - Ollins}

The coding of trial transcripts showed both routine and structural reasons for wrongful convictions in Ollins. These included currently recognized causes of error. There was evidence in the Ollins of racial profiling, false testimony, coerced confession, snitch testimony, poor investigation, poor forensic hair analysis, tunnel vision, and prosecutorial misconduct. Much of the questionable evidence was heard by the jurors, who still convicted the defendants.

\footnotetext{
${ }^{139}$ DuBow, supra note 91, at 14.

${ }^{140}$ Daniel Givelber, The Adversary System and Historical Accuracy: Can We Do Better?, in WRONGLY CONVICTED, supra note 100, at 253.

${ }^{141}$ Berger v. United States, 295 U.S. 78, 88 (1935).

142 Givelber, supra note 140, at 254.

${ }^{143} I d$.
} 
The root sociological causes of conviction error were racism, justice system culture, plea bargaining, and snitch testimony.

The crimes involved a group of African American sixteenyear-old teens being accused of attacking an upper-class white female. Like in the Central Park five case, the boys were accused as a pack. One suspect had an intellectual disability. The teens were stereotyped, and prosecutors arrived at conclusions against the weight of the evidence. The juveniles were subjected to aggressive and abusive interrogation techniques contaminated by suggestive facts and deception. This led to Bradford's false confession. The literature recommends that deceptive practices not be used in the interrogation of juveniles. ${ }^{144}$ The accused were tried as adults but were too young for the death penalty. Pamela Fish, the forensic expert, lied about the secretor evidence, and the hair evidence was unreliable. ${ }^{145}$ Semen and hair evidence was tested and found not to match the suspects. There was government misconduct including Brady violations. ${ }^{146}$ Omar Saunders was told what story to tell about this crime and when he refused, he too was charged and sent to prison. ${ }^{147}$

Prosecutors knew the blood type did not match any of the suspects' but withheld that information from the defense. ${ }^{148}$ Pamela Fish, considered an expert in forensic science serology, testified she had determined that the blood types found in the tested semen "could have" linked at least one of the defendants to the victim. ${ }^{149}$ This was

\footnotetext{
${ }^{144}$ See Hayley M.D. Cleary \& Todd C. Warner, Police Training in Interviewing and Interrogation Methods: A Comparison of Techniques Used with Adult and Juvenile Suspects, 40 LAW \& HUM. BEHAV. 270, 280 (2016) ("Reid manual is marginally more sensitive to adolescent developmental issues (e.g., suggesting caution when interpreting youth behavior) than the previous edition on which most academic literature is based, it nonetheless maintains that confrontational interrogations involving 'active persuasion' and even deception are permissible with adolescents, which the manual defines as ages 10-15.") (internal citations omitted); Saul M. Kassin et al., Interviewing Suspects: Practice, Science, and Future Directions, 15 LEGAL \& CRIM. PSYCH. 39, 44 (2010).

${ }^{145}$ Ollins, 2005 WL 730987 , at $* 1, * 3$.

${ }^{146} I d$. at *10.; Trial Tr. OLL-000766; Trial Tr. OLL-000758; Possley \& Mills, supra note 91 ("He [Bradford] said he falsely implicated himself and the others because police beat him during his interrogation - a claim his family also made just after his arrest when they said they saw him bruised."); DuBow, supra note 91.

147 Ollins 2005 WL730987 at *2; Trial Tr. OLL-000766; DuBow, supra note 91, at 14.

148 Ollins 2005 WL 730987 at *10; Trial Tr. OLL-000447 at 606.

149 Trial Tr. OLL-000606.
} 
fraudulent testimony since the tests concluded none could have been linked. ${ }^{150}$ Pamela Fish testified that the perpetrator or perpetrators were secretors. ${ }^{151}$ However, she determined through testing that the defendants were non-secretors who do not secrete their blood type into their bodily fluids. ${ }^{152}$ She was asked, "Someone else other than Larry Ollins could have deposited the semen?" to which Fish replied, "I cannot exclude him as depositing the semen." 153

\section{B. State of Maryland vs. Kirk Bloodsworth ${ }^{154}$}

A deep-dive into the trial transcripts of Kirk Bloodsworth show how underneath the main identified cause of this wrongful conviction, eyewitness misidentification, rush to judgement by detectives, and an overzealous prosecutor resulted in tunnel vision, poor investigation, forensic contamination, and government misconduct. Further, our findings indicate root structural causes, the adversary system, and media influence, contributed to the "perfect storm" by encouraging police and prosecutors to quickly find and arrest a suspect due to the inflammatory child rape and murder. ${ }^{155}$

\section{i. Background}

On July 25, 1984, police discovered the partially nude body of nine-year old Dawn Hamilton in a wooded area near Fontana Village Apartments in Rosedale, Maryland. ${ }^{156}$ The victim was found face down with signs of sexual assault and a fracture to her head from the

${ }^{150}$ Trial Tr. OLL-000607.
${ }^{151}$ Trial Tr. OLL-000599.
${ }^{152}$ Trial Tr. OLL-000598.
${ }^{153}$ Trial Tr. OLL-000615.
${ }_{154}$ Kirk

154 Kirk Bloodsworth, INNOCENCE PROJECT, https://www.innocenceproject.org/cases/kirk-bloodsworth/ (last visited April 18, 2020). The Kirk Bloodsworth case was coded by Tonya Kendall, Debra Fulton, and Amber Burke. Trial Tr. BLO-000014; Trial Tr. BLO-000506; Trial Tr. BLO-1087. ${ }^{155}$ Richard A. Leo \& Jon B. Gould, Studying Wrongful Convictions: Learning from Social Science, 7 OHIO STATE J. CRIM. L. 7 , 18 (2009). Leo \& Gould assert that most wrongful conviction cases are not due to one single cause but are the result of multiple factors that together create a "perfect storm" of errors leading to the conviction of an innocent person. Id.

${ }^{156}$ See Anthony Pipitone \& Jenny Abdo, Man Hunted in Girl's Murder, EvenING Sun, July 26, 1984, at A10. 
blow of a blunt force object. ${ }^{157}$ Christian Shipley, age ten, and Jackie Poling, age seven, who had been fishing nearby, recounted that Dawn had come up to them and asked if they had seen her cousin Lisa. Christian stated that an unknown man they had been talking to about their fishing expedition overheard Dawn and volunteered to help her find Lisa. The boys were reportedly the last ones to see Dawn as she walked into the woods with the stranger. ${ }^{158}$ Before sundown the same evening, law enforcement began a manhunt for the mysterious male. Detectives knocked on hundreds of doors in and around the apartments asking if anyone had seen a man whose description believed to be: white, early thirties, six feet tall, curly blonde hair, mustache, wearing a light shirt and tan shorts. ${ }^{159}$ The following day, the media released a composite sketch of the suspect, ${ }^{160}$ prepared by one of the child witnesses, giving rise to a flood of calls from concerned individuals who reported seeing the man who fit the description. ${ }^{161}$ An anonymous tip, number 286 of 500 such tips, lead to the arrest of Kirk Bloodsworth, age twenty-three. The tip reported that the vastly circulated sketch of the suspect resembled a man who worked for Harbor to Harbor. ${ }^{162}$ Bloodsworth became a suspect after the FBI prepared a psychological profile. Jay Miller, police spokesman at the time, announced, "[a]fter that profile was matched with Bloodsworth's background, several witnesses were able to place him at the Fontana Village Apartments on the day Dawn was murdered."163 It took only two and a half hours of jury deliberation and one hour of deliberation by the judge for Bloodsworth to be convicted of first-degree rape, firstdegree sexual assault and murder and sentenced to death plus two

${ }^{157}$ Larry Corson \& Frank D. Roylance, Man Arrested in Murder of Girl, EvENING Sun, Aug. 9, 1984 at A3.

${ }^{158}$ Elizabeth Hudson \& David Michael Ettlin, Rosendale Girl, 9, is Murdered; Police Seek Man Seen with Her, BALT. Sun, July 26, 1984, at A12.

${ }^{159} \mathrm{Id}$.

160 Drawing Issued of Slaying Suspect, Evening Sun, July 27, 1984, at D3 [hereinafter Drawing Issued].

${ }^{161}$ Larry Rosenthal, Baltimore Area Girl, 9, Found Slain, Morning News, July 26, 1984, at B4.

${ }^{162}$ Larry Corson \& Frank D. Roylance, Man Held in Girls Murder, Evening Sun, Aug. 9, 1984, at A1.

${ }^{163} \mathrm{Id}$. 
consecutive life sentences ${ }^{164}$ for this crime he did not commit. ${ }^{165}$ Bloodsworth had no criminal record and no history of violence. ${ }^{166}$

\section{ii. Eyewitness Misidentification}

Eyewitness identification is unreliable and is a major cause of wrongful convictions. Mistaken Witness Identification make up a third of all wrongful convictions (thirty-one percent). It is highest in sexual assault cases (sixty-nine percent). ${ }^{167}$ Bloodsworth had five independent witnesses identify him during a line-up. ${ }^{168}$ It is only through the painstaking task of coding the trial transcripts that revealed how this could happen to an innocent person. Most obviously noted were the inconsistencies of accounts and suspect descriptions given by eyewitnesses. The two primary witnesses in this case were the child eyewitnesses.

Further, jurors "said the eyewitness identification by five people who testified they saw him in the area of the apartment complex, and particularly of an 11-year-old boy who identified the defendant as the man he and his friend talked to and who he saw with Dawn, was 'the clincher.", 169

The evening of the murder, both children gave different descriptions of the man they saw at the pond. In his original statement, Christian Shipley described the man as: "A white male. About 6 foot 5, slim to medium build. Dirty blond, very curly hair."170 Jack Shipley

${ }^{164}$ Robert A. Erlandson, Kirk Bloodsworth gets Death Penalty in Child's Death, BALT. Sun, Mar. 22, 1985, at A7.

${ }^{165}$ Kirk Bloodsworth, supra note 154.

${ }^{166} \mathrm{Id}$.

167 Basic Patterns, NAT'L REGISTRY OF EXONERATIONS, http://www.law.umich.edu/special/exoneration/Pages/Basic-Patterns.aspx (last visited April 18, 2020).

168 See, e.g., Trial Tr. BLO-000035; Trial Tr. BLO-000051. According to the Detective Capel, Chris and Jackie identified Bloodsworth after they left the line-up room because they were scared to do so in front of the suspect. Both corroborated to this fact on the witness stand. $I d$.

${ }^{169}$ Robert A. Erlandson, Bloodsworth is Sentenced to Death, BALTIMORE SUN (Mar. 23, 1985), https://www.newspapers.com/image/377496986.

170 Trial Tr. BLO-000671-72.

A white male. About 6 foot 5, slim to medium build. Dirty blond, very curly hair. Light brown mustache. Tan Skin. Wearing an Ocean Pacific type short-sleeved pull-over shirt with quarter-inch triple stripes around the upper chest area, the stripes he thought were like red, orange, and wine. 
inconsistently described the man as, "[twenty-five] years old, short and skinny with short brown hair, wearing a pair of dark shorts and a shirt," according to the detective. ${ }^{171}$

After interviewing the children, the detective worked with just Chris, because Jack was "so unsure of the different features," to create a composite drawing of the suspect. ${ }^{172}$ When asked by the defense if Chris thought the composite looked like the man he saw, the detective testified that Chris was not satisfied with the hair, the eyes, or the mustache. "[H]e felt the hair was unruly and also a lighter color than what showed up on the composite." 173

Although the young eyewitness was not happy with the outcome of the composite, law enforcement decided to use it because "[they] wanted to get the composite out to the press right away." 174 Detective Capel testified that, "[i]t seems like [sketch artists] can do wonders, but when you put their sketches together, it all looks like the same face, apparent, at least, to me ... . [A]lso, they charge money."175

\section{iii. $\quad$ Forensic Error}

Officers did not prevent contamination of the crime scene even after it was discovered to be a crime scene. Officers did not prevent anyone from handling evidence. The father of the victim handled the victim's shorts and underwear as well as other evidence including a literature flyer, cigarette butts, and a pack of cigarettes. Another suspect, Richard Gray, is the person who led the victim's father to this

\footnotetext{
Light tan walking shorts with red stitching. White knee calf-length socks with dark stripes at the top. Light colored tennis shoes.

Id.

171 Trial Tr. BLO-000673.

172 Trial Tr. BLO-000032.

173 Trial Tr. BLO-000035-36.

He wasn't completely satisfied with it .... [I] did the hair and that took quite some time and he wasn't completely satisfied....[H]e felt it was unruly and also a lighter color than what showed up on the composite. . . [W] had a lot of problems with the eyes, and he was never completely satisfied with the eyes. ... He] wasn't happy with the mustache, either.

Id.

174 Trial Tr. BLO-000034.

175 Trial Tr. BLO-000035.
} 
evidence. ${ }^{176}$ There was never an attempt to keep people from walking around the crime scene. Coding reveals:

Mr. Gray has already passed the panties that are in the tree and the shorts. . . . [M]r. Gray says, I found some panties in the tree. They photograph his car and what do they find? . . . [T] hey find a pair of panties. Now, this is a man who has just passed a tree where $\mathrm{D} \mathrm{H}$ panties are hanging. ${ }^{177}$

Coded trial transcripts also showed how inadequate forensics played a role in Bloodsworth's erroneous conviction. According to the defense, microscopic examination of the victim showed many spermatozoa present and the vaginal smear showed a few sperm. However, the FBI stated that there were no sperm present on the vaginal swabs and there was no report of what happed to the sperm present in the rectal.

Nobody ... took a blood sample of Kirk Bloodsworth. ... No one took sperms of him to determine if he's a secretor non-secretor. . . . [E]ven though you cannot identify who committed the crime with this method, you can eliminate someone who committed, who might be a suspect. ${ }^{178}$

Forensic evidence may have determined if the residue was from a secretor or non-secretor. This may have eliminated possible suspects.

\section{iv. Tunnel Vision}

When law enforcement is driven by tunnel vision, they tend to focus on evidence that supports their suspicion of a person's guilt and discount information as unreliable or not credible that points away from that belief. ${ }^{179}$ This drive to confirm a person's guilt negatively

\footnotetext{
176 See Bloodsworth v. State, 543 A.2d 382, 396 n. 19 (Md. Spec. App.); see also Bloodsworth, 512 A.2d 1056, 1059-60 (regarding additional evidence that rendered Gray a suspect that was not revealed to defense constituting Brady violation).

177 Trial Tr. BLO-001190.

178 Trial Tr. BLO-001200-01.

${ }^{179}$ Katherine Judson, Bias, Subjectivity, and Wrongful Conviction, 50 U. MicH. J.L. REFORM 779, 784 (2017); Martin, supra note 105.
} 
impacts nearly every stage of the investigation found in each known case of erroneous conviction. ${ }^{180}$

As mentioned in the background section of this case, there were 500 tips in this case. Of those 500, the head detective testified that only a couple of individuals named Kirk Bloodsworth ${ }^{181}$ by name after seeing the composite drawing. ${ }^{182}$ The coded transcripts revealed this explanation for why Kirk was considered: The two detectives that investigated Mr. Bloodsworth and went to Harbour and Harbour came away with very strong feelings that this was a potential prime suspect. ${ }^{183}$

In response, the detectives traveled to Bloodsworth's hometown, where he was staying, to interview him and take his photo after suspects named him after seeing the composite. During that very first interview, the detectives created a false narrative through the use of a pair of purchased girls' panties and a rock they picked up the outside the parking lot to get a reaction from Bloodsworth. The following was revealed in the transcripts:

Defense: Now, what was of the little skit you had with Ramsey with putting the panties and rock on the table and then taking them off real fast?

Detective Capel:[i]f the murderer came into the room and viewed these articles even for a short period of time, it would cause a trauma and some type of reaction $\cdots$

Defense: All right. And as you testified, as far as you could tell, there was no reaction.

\footnotetext{
${ }^{180}$ Martin, supra note 105.

181 Trial Tr. BLO-000047.

182 Trial Tr. BLO-000048.

${ }^{183} \mathrm{Id}$.
}

Defense: What I am trying to develop is how you first focused in from five hundred names, or if I recall correctly, some of them weren't names, but a good two hundred names given as suspect?

Detective Capel: Yes

Defense: Of the two hundred names of people who say that composite is Pete Smith or whoever, out of those two hundred, what I'm trying to develop is how you zeroed in on ... ?

Detective Capel: The two detectives that investigated Mr. Bloodsworth and went to Harbour and Harbour came away with very strong feelings that this was a potential prime suspect.

Id. 
Defense: Therefore, according to your theory, that would tend to show that he was innocent as far as you were concerned?

Detective Capel: No, sir. ${ }^{184}$

After the detectives returned to the station with the polaroid picture taken of Bloodsworth during the interview, they prepared a photo array to show the child witnesses. Coded transcripts revealed that the photo array deceptively portrayed only Mr. Bloodsworth and another with a mustache description that the child (Chris Shipley) had provided. ${ }^{185}$ Jack Poling was unable to identify Bloodsworth in the photo array, but Chris Shipley did. As a result, Kirk Bloodsworth was arrested.

\section{Structural Causes: Media EfFect ANd AdVersarial SYSTEM}

\section{A. The Media Effect}

When a child is a victim, especially one of sexual assault, the news media disproportionately prioritizes the coverage. ${ }^{186}$ This creates fear in the public ${ }^{187}$ and pressure on law enforcement. ${ }^{188}$ The additional eyewitnesses did not come forward until continued coverage regarding the "child rape and murder" and the release of the composite

${ }^{184}$ Trial Tr. BLO-000688.

185 Trial Tr. BLO-000051.

Defense: [w]hat is the description given to you by Mr. Shipley?

Detective Capel: Mustache

Defense: [b]ut then you show him photographs of which the photographs have only two other people in the photographs other than Mr. Bloodsworth have mustaches. Isn't that correct?

Detective Capel: That's correct. No. Actually there were three besides Mr. Bloodsworth.

Defense: Photograph number three has a mustache, but he has a full beard.

Id.

${ }^{186}$ Rebecca A. DiBennardo, Ideal Victims and Monstrous Offenders: How the News Media Represent Sexual Predators, 4 Socius: Socio. Rsch. DyNAMIC World 1, 4 (2018).

${ }^{187}$ Kenneth Dowler, Media Consumption and Public Attitudes Toward Crime and Justice: The Relationship Between Fear of Crime, Punitive Attitudes, and Perceived Police Effectiveness, 10 J. CRIM. Just. \& POPULAR CUlture 109, 110-11 (2003).

${ }^{188}$ Keith A. Findley \& Michael S. Scott, The Multiple Dimensions of Tunnel Vision in Criminal Cases, 2006 WIS. L. REv. 291, 323-24 (2006). 
sketch in the media. When asked if the composite was published across all major newspapers and television stations, the detective replied, "Yes ... [i]t was very widely publicized."189 Moreover, the physical description that accompanied the composite said, "[p]olice are searching for a blond, curly-haired man, described as in his 30s, about 6 feet tall with a mustache ... [b]ased on descriptions supplied by the boys and other witnesses." 190 Kirk Bloodsworth's description, less than two weeks after the murder, according to his arrest report was "age 23, heavy build, 6 feet tall, red hair, green eyes."191

Law enforcement received three additional eyewitness descriptions because of the widespread media coverage. Each of the eyewitnesses identified Bloodsworth in a line-up and testified at trial. What became apparent from the coded transcripts is the different descriptions that each witness testified to when asked by the State to describe the man they saw, and consequently, picked out of the lineup. Donna Ferguson told detectives that she saw an unknown man with Dawn between 10:15-10:30 a.m. the day of the murder. She testified that the man was "age $25,26 \ldots$. [a]pproximately 6 foot tall, built big, broad shouldered ${ }^{192} \ldots$. [a]nd orange hair due to the sunlight. .. . [I]t was like strawberry blonde." "193 However, Detective Capel testified that her original description of the suspect was "about 30years-old, blonde collar length wavy hair, unknown facial hair, wearing light colored clothing." 194

Hall testified that what she remembered most about the man "is his hair and his eyes. . . . [H]e just had like that frizzy hair . . [ [j]ust staring at me." 195 This was the only statement she gave on the stand regarding the man's description. ${ }^{196}$ Capel testified that Nancy Hall described the man as " 6 foot tall, thin, late 20 's, dark hair, wearing a burgundy short-sleeved shirt trimmed in black and black cuffed long pants" sitting on a green electrical box on the corner of her street. Capel said that Ms. Hall told him that she had seen the man between 5

189 Trial Tr. BLO-000039.

${ }^{190}$ Drawing Issued, supra note 160.

191 Trial Tr. BLO-000683.

192 Trial Tr. BLO-000629.

193 Trial Tr. BLO-000082.

194 Trial Tr. BLO-000702-03.

${ }^{195}$ During the Motion to Suppress Hearing, BLO-000109, Nancy Hall stated his hair looked "like an afro-looking thing. "He had beady eyes. His eyes looked dark. His hair was real shiny. Like strawberry-blonde looking." Trial Tr. BLO-000510.

196 Trial Tr. BLO-000510. 
p.m. and 6 p.m. on two different occasions within the week of the murder, sitting on a green electrical box on the corner of her street. ${ }^{197}$ James Keller testified that the individual he identified from the line-up was the same person he saw on his way to work July $25^{\text {th }}$. However, when asked to describe the man, Mr. Keller replied, "[w]ell, like I said, he was a heavy-set person, ... [h] e was wearing shorts and a light-colored shirt, ${ }^{198} \ldots$. [b]lond headed, so mustache must have been the same." 199

Considering that the eyewitness description testimony of the man is uncannily similar to the description in reported news coverage, this suggests that they too, were influenced by the media. This is something that their individual testimony indicates when defense counsel asked each eyewitness if they saw news coverage about the composite or Mr. Bloodworth's arrest.

Nancy Hall recalled that she first realized that the person she saw on the box was the person the police were looking for "because I seen (sic) him on the news. . . . [I] had forgotten like . . . [t]hen I remembered. ... [A]11 night I freaked out." 200

Mr. Keller stated, "Yes, I did. I seen him, the man. I seen (sic) the man on television. You asked me what did I see on television.... [W]ell, you know, how they show, you know, picture."201

Ms. Ferguson denied seeing the composite or Mr. Bloodsworth through the media but did mention that the police had gone to her home and "showed her sketches," and that the story "was posted everywhere, the ice cream man, everything I can think of had it." 202

\section{B. Role of the Adversary System/Overzealous Prosecution}

A hair was found at the scene that did not belong to Mr. Bloodsworth. DNA evidence was not linked to Mr. Bloodsworth. The eyewitness descriptions were inconsistent and contradictory. A composite sketch was released to the public for leads even though

\footnotetext{
197 Trial Tr. BLO-000707-08.

198 Trial Tr. BLO-000535.

${ }^{199}$ Trial Tr. BLO-000185.

200 Trial Tr. BLO-000112.

${ }^{201}$ Trial Tr. BLO-000185.

${ }^{202}$ Trial Tr. BLO-000093.
} 
Christian Shipley said it did not satisfactorily look like the man he saw. Based on the trial transcripts, there were two hundred other tips naming a suspect, most of which were not followed up. The trial transcripts uncovered a statement made to the jury, saying, "Are we supposed to bring everybody in here from Baltimore County, everybody who lives in that area, everybody who has ever been seen within the last couple weeks around this crime? Strangers?"203 Thus, we can conclude that few of the Remaining 494 tips, naming 200 different potential suspects, were followed up by law enforcement.

Yet, the prosecutor opted to charge Kirk Bloodworth with capital murder. Rather than striving for justice, the prosecution attempted to win the case instead. When the State knew that their faulty eyewitness testimony was not enough, they persisted to win the case at all costs. It is submitted that the statement below by the prosecutor in this case shows that the State knew that they did not prove guilt. $^{204}$

I would also submit to Your Honor that no physical evidence has shown that someone else did this. It simply has been neutralized, as matter of fact. Certainly, it doesn't link the defendant with the offense, but it certainly doesn't show that someone else committed the crime.

The prosecutor with the assistance of Police testimony used knowledge of the rock shown to Bloodsworth during the initial interview as evidence of his guilt. "We asked Kirk how could he have known about the bloody rock when only a few police officers and the murderer would know about a bloody rock." 205

203 Trial Tr. BLO-001243.
204 Trial Tr. BLO-001138.
205 Trial Tr. BLO-001206-07.

We asked Kirk how could he have known about the bloody rock when only a few police officers and the murderer would know about a bloody rock.

Prosecutor: Detective, did you observe any unusual behavior on the part of the Defendant during your interview with him?

Prosecutor: Now, did you at any time during that interview or the interview that preceded it indicate to the Defendant what had happened to the victim other than that she was murdered?

Detective: No,... [t]hat was one of the points we brought out. We asked Kirk how could he have known about the bloody rock when only a few police officers and the murderer would know about a bloody rock. 
This knowledge contaminated the evidence, and the unreliable suggestive tactics are similar to the Central Park Five case where police showed the boys the crime scene and used the knowledge of the scene against them. ${ }^{206}$

The prosecutor put on evidence that a shoe obtained during a search warrant belonged to Bloodsworth even though his sister-in-law advised the detective's the shoes and clothing they removed from the house did not belong to Kirk. The defense attempted to rectify the situation by explaining to the jury that the shoe found during the search was a size eight, and the defendant wore a size ten. ${ }^{207}$

The statement did not mitigate the damage, however, because one of the jurors, who wore a size $101 / 2$, tried on the shoes in the jury room and could wear them. ${ }^{208}$ They deemed this as one of the strongest factors of Bloodsworth's guilt — a man with a size $10^{1 / 2}$ foot could wear a size 8 shoe. ${ }^{209}$

There were several Brady violations regarding an alternate possible suspect, Richard Gray. The prosecution never advised defense attorneys of alternate suspects required under Brady $v$. Maryland. ${ }^{210}$ The officers did a poor investigation at the crime scene and the detectives had tunnel vision. The defense requested all thirty eyewitness statements, but the prosecution argued that "[i]t is clear we don't have to turn over witness statements unless and until that witness testifies in the State's case in chief." 211

During closing arguments, the State used the following tactics to address its lack of evidence:

\footnotetext{
Id.

${ }^{206}$ See infra Section VI.

${ }^{207}$ Trial Tr. BLO-000683.

Detective Ramsey comes in here and tells us that he measured the shoes and it was a size ten and a half. The State's Attorney puts on that evidence. ... [H]e was wearing these shoes and that they can prove its Kirk Bloodsworth the murderer because the impression on the girl's neck came from these shoes. That's the logic . . . [r]eiterated through the State's Attorney . . . indeed this is not a size ten. It's a size 8 shoe.

Id.

${ }^{208}$ Anthony Pipitone, Bloodsworth Jury Convinced of Guilt from the Start, EvENING Sun, Mar. 25, 1985, at C1.

${ }^{209} I d$.

210373 U.S. 83, 84 (1963) (holding that prosecutors must disclose all evidence that could be materially favorable to the guilt or punishment of defendant regardless of good or bad faith).

${ }^{211}$ Trial Tr. BLO-000014.
} 
When the shoeprints did not match Bloodsworth's shoe taken upon arrest: "It does not point the Defendant, and we candidly admit that to you all, but neither does it eliminate him." 212 When the hair did not belong to Bloodsworth: "we don't know whose hair that is but let me point out that that doesn't point the finger at anyone else, only that it isn't his hair." 213

Eyewitness discrepancies: "The last thing they want to do is to have the wrong man, because if they did, that would mean the man who committed these atrocities against $\mathrm{D} \mathrm{H}$ is still out there, so when they come in here and tell you that that's the man they saw, they are sure because they have to be." 214

Regarding other suspects: "They are not on trial. Mr. Gray is not on trial. Mr. Mansari is not on trial. The Defendant is on trial. The five witnesses didn't identify Mr. Gray. They didn't identify Mr. Mansari. They identified the Defendant." 215

Addressing the hair in rebuttal: "Who knows whose hair that is? It doesn't incriminate him. It doesn't eliminate him. It's neutral. It does zero." 216

\section{Lack of Sperm:}

By the time he sees whether there are sperm on these slides, that body has been buried. Now, I would assume or suppose that Mr. Sheinin would have that body dug up and that Doctor Smyth go back in there and try to find some sperm, if it is still around, that hasn't been totally destroyed by bacteria and et cetera in an effort to try to prove something in this case. ${ }^{217}$

Appeal of sensibility: "Deciding cases is common sense. . . .[T]hat's what it takes to decide this case. I would ask you to use that gift of common sense that God has given you."218

\footnotetext{
${ }^{212}$ Trial Tr. BLO-001166.

${ }^{213} I d$.

${ }^{214}$ Trial Tr. BLO-001171.

215 Trial Tr. BLO-001243.

216 Trial Tr. BLO-001246.

217 Trial Tr. BLO-001247.

218 Trial Tr. BLO-001261.
} 


\section{Conclusion-Bloodsworth}

Kirk Noble Bloodsworth was the first American sentenced to death to be exonerated post-conviction by DNA testing. ${ }^{219}$ The case is famous for mistakes attributed to tunnel vision, media bias and misconduct. As a result, Senator Patrick Leahy of Vermont, interviewed by students below, sponsored Kirk Bloodsworth PostConviction DNA Testing Grant Program, under the Innocence Protection Act, which guaranteed funding for post-conviction DNA testing. 220

The Bloodsworth case was a tragic and bloody child rape and murder case. This led to a rush to judgment and tunnel vision, media bias and sensation and both wrongful conviction error and misconduct. The routine causes of the wrongful conviction in this case included eyewitness misidentification, forensic contamination, tunnel vision and prosecutorial misconduct. The structural causes, evident from the transcripts, included the adversary system culture and media which encouraged police and prosecutors to find and arrest a suspect due to the inflammatory child rape and murder.

Kirk Bloodworth's conviction was based mainly on incorrect eyewitness testimony as well as misconduct and poor investigation. While reforms for eyewitness identification may avoid these errors, law enforcement tunnel vision and police misconduct are structural problems related to the adversary system, not easily reformed.

Law enforcement should have branched out their suspect pool rather than focus on only one person. A simple chart would show the differences with the descriptions. There were Brady violations regarding Richard Gray, and the prosecution never advised defense attorneys of alternate suspects. There was poor investigation and tunnel vision. Officers did not prevent contamination of the crime scene even after it was discovered to be a crime scene. Officers did not prevent anyone from handling evidence. The photo array was not administered properly — all subjects did not have similar features. The prosecutor's inflammatory closing argument inflamed the jurors, calling for the maximum sentence, without any evidence. ${ }^{221}$ "We are dealing with a nine-year old little girl, who before the life was strangled

${ }^{219}$ Kirk Bloodsworth, supra note 154.

${ }^{220}$ Kirk Bloodsworth Post-Conviction DNA Testing Grant Program, 34 U.S.C.A. $\S 40727$ (West).

${ }^{221}$ Trial Tr. BLO-001138. 
and crushed out of her, was raped, and sodomized and a branch shoved up her vagina. The absolute terror and horror of such an offense can hardly be described . .."222

\section{PeOple OF The State OF NeW York VS. KHAREY (KoRey) WISE AND KEVIN RICHARDSON ${ }^{223}$}

\section{A. Background}

A review of the transcripts in the Wise and Richardson cases show many of the canonical routine and structural factors found in the Ollins and Bloodsworth cases discussed above. Wise and Richardson (tried together) were two of the five teens wrongfully convicted in the infamous Central Park Five exoneration cases. Three other teens were tried together first, and also wrongfully convicted (Antron McCray, Raymond Santana, Yusef Salaam). The decisions to try the cases separately or together were based on what the boys had said in their confessions. As in Ollins and Bloodsworth, the canonical factors here included coerced juvenile confessions, racial profiling, poor investigation, poor forensic analysis, overzealous prosecution, tunnel vision, and misconduct. The root sociological causes of the conviction error included racism, justice system culture, the adversarial system, media distortion, and public sensationalism. During an era of high crime and racial stereotype and threat in New York, Lofquist demonstrates the structural and contextual causes of the wrongful convictions in this case stating that the black and Hispanic teens from

\footnotetext{
${ }^{222} I d$.

223 The Innocence Record, INNOCENCE PROJECT, https://www.innocencerecord.org/Pages/Home.aspx?ReturnUrl=\%2f_layouts\%2fA uthenticate.aspx \%3fSource\%3d\%252fRedacted\%252520Documents\%252fCPJ $\% 2$ $52 \mathrm{~d} 011343 \% 252 \mathrm{ePDF} \&$ Source $=\% 2 \mathrm{fRedacted} \% 2520$ Documents $\% 2 \mathrm{fCPJ} \% 2 \mathrm{~d} 0113$ 43\%2ePDF\#search=\%22CPJ\%22 (last visited April 23, 2021). The transcripts in these cases were uploaded from the Innocence Record, Trial Tr. CPJ-011343 at 2052284; Trial Tr. CPJ-012257 at 2259-3150; Trial Tr. CPJ-012646 at 3349-521; and Trial Tr. CPJ-009479 at 184-386. The facts of the cases are summarized from the Innocence project web pages and from the documentary, "The Central Park Five." This section was coded and written by Kathryn Pooters and Candace Barrow at Hartwick College and Tonya Kendall. Kevin Richardson, InNOCEnCE ProJeCt, https://www.innocenceproject.org/cases/kevin-richardson/ (last visited April 18, 2020); Korey Wise, INNOCENCE PROJECT, https://www.innocenceproject.org/cases/korey-wise/ (last visited April 18, 2020). Richardson and Wise were tried together. BURNS, supra note 16.
} 
Harlem were targeted more because of who they were rather than what they did. 224

The defendants in this case were vulnerable to wrongful convictions. Their vulnerability was much more a product of who they were and the relationships between their community and the criminal justice system, than of the particular circumstances of their cases. They were the usual crime subjects before they were the usual rape subjects ... . 225

On the evening of April 19, 1989, serial rapist Matias Reyes brutally raped and almost killed a twenty-eight-year-old female jogger, Trisha Meili, a Wall Street investment banker, in Central Park, New York City. Reyes was a serial rapist and murderer who had committed crimes before victimizing Melli, and the wrongful arrests enabled the perpetrator to continue his crimes. ${ }^{226}$ Five African American and Hispanic teens were interrogated, arrested, and wrongfully convicted for the crime. ${ }^{227}$ They were Kevin Richardson, Antron McCray, Raymond Santana, Yusef Salaam, and Kharey (Korey) Wise. ${ }^{228}$ Each spent between seven and thirteen years in prison. ${ }^{229}$ There was

${ }^{224}$ Lofquist, supra note 1, at 22-23.

${ }^{225} \mathrm{Id}$. at 22.

${ }^{226}$ NORRIS ET AL., supra note 6.

${ }^{227}$ A New York City teacher says she was fired for teaching her students about the Central Park Five, InNOCENT PROJECT (Jan. 8, 2016), https://innocenceproject.org/anew-york-city-teacher-says-she-was-fired-for-teaching-her-students-about-thecentral-park-five/.

${ }^{228} I d$.

${ }^{229}$ In re McCray, Richardson, Santana, Wise, and Salaam Litig., 928 F. Supp. 2d 748, 751 (S.D.N.Y. 2013). Film production company moved to quash defendants' amended subpoena, which sought production of audio or video materials regarding certain interviews conducted during creation of documentary regarding plaintiffs' experiences. Antron McCray, Kevin Richardson, Raymond Santana, Kharey Wise, and Yusef Salaam (collectively, the "main Plaintiffs") each served prison terms ranging from seven to thirteen years in prison after being convicted for the 1989 attack on Trisha Meili, long known to the public as the "Central Park Jogger." In 2002, another man's confession and DNA evidence led the district attorney's office to recommend vacating the main Plaintiffs' convictions. On December 19, 2002, the convictions were vacated by order in the New York Supreme Court. In 2003, the main Plaintiffs and their families filed suit against the City of New York, the New York City Police Department, the New York County District Attorney's Office, and certain employees and agents of these offices (collectively, "Defendants") who Plaintiffs assert, inter alia, conspired and perpetuated false evidence in securing the main Plaintiffs' convictions. (citations omitted); BURNS, supra note 16, at ix. 
prosecutorial and investigatory misconduct, as well as an intense media frenzy. ${ }^{230}$ The defendants confessed to these crimes after coercive interrogation, and the confessions were the primary evidence to convince the jury despite an inconsistent timeline and faulty forensic evidence. $^{231}$

A group of youth which may have included some of the accused, were participating in disruptive activities in Central Park on this warm Spring evening. Front page headlines of the Daily News recounted this using inflammatory language like "wolfpack" and "wilding." 232 As in the Ollins case, the police erroneously focused much of their investigation on the nearby low-income Harlem housing projects where mostly African Americans and Hispanic families lived, including the Schomburg Plaza complex where Korey Wise lived. ${ }^{233}$ New York City in the 1980s was clearly divided by color and overwhelmed with drug and violent crime. The media enhanced the fear of the public and used many racially charged phrases in their headlines. ${ }^{234}$ Racial stereotyping, confirmation bias, and tunnel vision led police to coercively interrogate the wrong juvenile suspects, convinced of guilt which conformed to racial stereotypes. ${ }^{235}$

\section{B. The Park ${ }^{236}$}

Fourteen-year-old African American Kevin Richardson lived with his mother Gracie Cuffee in the same northeast tower of

230 "The Central Park Five": A Telling Account of Injustice and Lives Restored, INNOCENT PROJECT (Sept. 19, 2013), https://innocenceproject.org/the-central-parkfive-a-telling-account-of-injustice-and-lives-restored/ [hereinafter "The Central Park Five"].

${ }^{231}$ In re McCray, 928 F. Supp. 2d 748, 751; BuRNS, supra note 16, at ix.

${ }^{232}$ BURNS, supra note 16, at 117; "The Central Park Five", supra note 230; Trial Tr. CPJ-011343 at 2055-56; see also King, supra note 16; N.Y. State Writer's Institute, supra note 16.

${ }^{233}$ BURNS, supra note 16 , at 4-6.

${ }^{234}$ Id. at 69-70 ("Wolfpack's Prey, Nightmare in Central Park, and Wilding").

${ }^{235}$ O'Brien \& Findley, supra note 2, at 36; Drizin et al., supra note 2, at 169; Tepfer et al., supra note 62 .

${ }^{236}$ Kevin Richardson, supra note 223. Kevin Richardson's date of arrest: Apr. 19, 1989; Age of Accused at time of crime: Fourteen; Race of Accused: African American Male; Race of Victim: Caucasian Female; Age of Victim at time of crime: Twenty-eight. Kevin Richardson, supra note 223. Korey (Kharey) Wise's date of arrest: Apr. 20, 1989; Date of trial: Nov. 22, 1990; Date of exoneration: Dec. 19, 2002; Race of Accused: African American Male; Race of Victim: Caucasian Female; Age of Victim at time of crime: Twenty-eight. Korey Wise, supra note 223. 
Schomburg plaza facing Central Park as Korey Wise and Yusef Salaam. ${ }^{237}$ On the evening of April 19, 1989, Richardson had joined a group of about thirty-three boys at the northeast entrance to Central Park which included himself, Korey Wise, Yusef Salaam, Antron McCray and Raymond Santana. Santana and McCray lived in the nearby Taft housing project. There were incidents in the park: Michael Vigna rode his bike on East Drive at 9:05 p.m., and some members of the group blocked his way and swung at him. A homeless drunk, Antonio Diaz was knocked to the ground, and youths took his food. At 9:12 p.m., Gerry Malone and Patricia Dean, riding a tandem bike, were blocked by members of the group. ${ }^{238}$ Police showed up on $97^{\text {th }}$ Street, and Korey left the park and went home. Yusef climbed a wall towards the reservoir finding Steve Lopez. Officers began looking for the boys. Officer Robert Powers caught Kevin Richardson and tackled him. He left a scratch on Richardson's left cheek with his helmet. ${ }^{239}$ That abrasion would be a piece of evidence that would be used to send him to prison. ${ }^{240}$ Richardson was taken to the Central Park Precinct where Lopez and Santana were held.

\section{i. The Interrogations: False Juvenile Confessions}

Kevin was held and interviewed by police throughout the night and into the next day without sleep or food and wound up giving several statements to police. ${ }^{241}$ Kevin explained being in the Park, but none of it included an assault on a female jogger. In a second interview, Kevin told them about the officer who had scratched his face; the investigators deemed this scratch to be very important to their case. ${ }^{242}$ When the investigator told Kevin that he would call the "white cop" that scratched him to verify the story, Kevin faltered and said he got it from the "girl we were fighting," but never mentioned the jogger. ${ }^{243}$ On the third interview, the police advised Kevin that his codefendants were saying that he is the one who raped and beat the jogger so he better tell the "truth." 244 During his videotaped coached

\footnotetext{
${ }^{237}$ BURNS, supra note 16 , at 6 .

${ }^{238} I d$. at $21-22$.

${ }^{239} \mathrm{Id}$. at 27-28.

${ }^{240} I d .40-41$.

${ }^{241} \mathrm{Id}$.

${ }^{242} I d$.

${ }^{243} \mathrm{Id}$.

${ }^{244} I d$.
} 
"confession," Kevin denied raping the victim but stated he received the scratch from her during the attack. ${ }^{245}$

Korey (Kharey) Wise was a sixteen-year-old African American youth who lived in the same neighborhood as his co-defendant. ${ }^{246}$ Wise had left the park earlier than the other boys, saying he was having a haircut. He was picked up the next day when the police were looking for Kevin Richardson and found out that Korey may have been a part of the activities in the Park. ${ }^{247}$ He voluntarily came to the police station for questioning, ${ }^{248}$ and he was not mentioned in anyone else's interrogation. ${ }^{249}$

Korey is hearing impaired and learning disabled. His intellectual capabilities equaled those of a twelve-year-old. ${ }^{250}$ Despite this, he was considered an adult under NYS law for interrogation purposes and in the corrections system. He did not have any family members or an attorney present during questioning. During his time at the police precinct, Korey had not slept and was only given a doughnut and juice as a meal. ${ }^{251}$ The officer testified at trial, "I gave him donuts and juice." 252 When Korey was questioned, a detective told his mother that he was going to be released because he did not know about the occurrences in the park. ${ }^{253} \mathrm{He}$ was told he could go home if he could tell the officers the story they wanted to hear. ${ }^{254}$ The next morning when Kharey's mother was looking for him, she went to the precinct to find out that her son had been arrested on sexual assault charges. $^{255}$

\section{ii. $\quad$ Miranda Rights; Crime Scene Visit; Prosecutorial Misconduct}

After the first wave of convictions, Kevin and Korey were tried together on November 22, 1990. Three trial transcripts were coded in

\footnotetext{
${ }^{245}$ Trial Tr. CPJ-011343 at 2063-118.

${ }^{246}$ BURNS, supra note 16 , at 4-6.

${ }^{247}$ Trial Tr. CPJ-012257 at 3042.

${ }^{248}$ BURNS, supra note 16, at 44-46.

${ }^{249}$ Trial Tr. CPJ-011343 at 2063-118.

${ }^{250}$ BURNS, supra note 16 , at 4-6.

${ }^{251}$ Trial Tr. CPJ-012257 at 3042.

${ }^{252} I d$.

${ }^{253} I d$.

${ }^{254}$ BURNS, supra note 16 , at 48 .

${ }^{255} \mathrm{Id}$. at 53.
} 
this case. ${ }^{256}$ At trial, the detective testified that he read Wise his Miranda rights and that Wise acknowledged that he understood the rights. ${ }^{257}$ The inadequate Miranda warnings were administered to someone with the intellectual ability of a twelve-year-old, despite the fact that he did not understand the consequences of speaking with an officer without an attorney.

During his interview, Korey Wise indicated he was not in Central Park when the assault occurred. He provided an alibi that he was having a haircut, an alibi not reported in the media. ${ }^{258}$ This was ignored by interrogators. Korey then gave a statement describing some of activities that occurred in the park, but he did not mention a female jogger. He described where he was when he thought the police entered the park, and he stated where he exited the park before the rape occurred.

Six hours after the police interrogation, Assistant District Attorney Linda Fairstein read Mr. Wise his Miranda warnings again for her questioning. The warnings were recited in a noisy, chaotic room to a juvenile who was hearing and learning impaired. 259 After the Miranda warnings and before the confessions, ADA Fairstein, Kharey Wise, Kevin Richardson, and some detectives went to the crime scene together. Both youths were asked to explain where the jogger was grabbed and where the "raping happened." 260 Neither gave an exact location, but a detective showed the suspects where the assault occurred and asked, "Does this look familiar?"261 False memories were now planted in the minds of these boys, before the confessions. This was an area where the suspects were allowed to enter before their clothing was placed into evidence. There, they saw a lot of blood. ${ }^{262}$

${ }^{256}$ Trial Tr. CPJ-011343 at 2052-284; Trial Tr. CPJ-012257 at 2259-3150; Trial Tr. CPJ-012646 at 3349-521.

${ }^{257}$ Trial Tr. CPJ-012257 at 3086-88; BURNS, supra note 16, at 49.

${ }^{258}$ Trial Tr. CPJ-011343 at 2063-118; Trial Tr. CPJ-012257 at 2259-3150. Detective Sheehan is cross-examined and questioned about his involvement in the case with Korey Wise. BURNS, supra note 16, at 49. Detective Sheehan was not informed about who the other detectives were on the case. Id.

${ }^{259}$ Trial Tr. CPJ-012257 at 3086-88; Julia Jacobs, Elizabeth Lederer, Prosecutor of Central Park Five, Resigns From Columbia Law, N.Y. TIMES (June 12, 2019), https://www.nytimes.com/2019/06/12/arts/elizabeth-lederer-central-park-five.html_ ("Ms. Fairstein was portrayed as the driving force behind the prosecution, ignoring evidence that did not validate her belief that the boys were guilty.").

${ }^{260}$ Trial Tr. CPJ-012257 at 3140; BURNS, supra note 16, at 52.

${ }^{261}$ BURNS, supra note 16 , at 52 .

${ }^{262} I d$. at $52-53$. 
Not only were the police influencing recollections, but they were possibly tainting evidence at the scene of the crime as well.

\section{iii. $\quad$ Forensic Evidence; Crime Lab Negligence; Ineffective Assistance of Defense Counsel}

Forensic evidence was available in this case but was not utilized as it should have been. Police never tested the fingernail scrapings of the victim. They did not test skin, hair, or serological evidence that might have excluded these suspects. ${ }^{263}$ Had they done so, they would have found that this forensic evidence was a match to the correct perpetrator and not a match to any of the five suspects in this case. Matias Reyes had been detained by police on another case and was known to be in the area. ${ }^{264}$

The defense team also should have investigated the crime scene more thoroughly. A photo of the crime scene shows a narrow path accommodating only one perpetrator, instead of the alleged gang of five. There was a clear timeline of events that occurred in Central Park that evening, but neither the defense nor the prosecution followed through on the timeline.

\section{iv. Defendants' Mental Impairments}

Kharey Wise was hearing impaired and intellectually disabled. ${ }^{265}$ This is relevant in assessing the voluntariness of waiving Miranda rights. The defense attorneys did not know their clients' life stories well enough to defend them. Wise's confession took place with neither an attorney nor a parent present. Kevin Richardson also had a learning disability that was never brought out at trial. His character witness mentioned it, but Kevin's attorney had "no interest in that at all" and was "not pursuing it." 266 The coding of the transcripts revealed information about these disabilities, not discussed in the proprosecution media sources.

\section{v. Absence of Evidence Regarding Kharey's}

\footnotetext{
${ }^{263} I d$. at 91-93, 96-97.

${ }^{264} I d$. at $27,114-23$.

${ }^{265} \mathrm{Id}$. at $4-5,106-07$.

266 Trial Tr. CPJ-012257 at 3140. This record contains the direct examination of character witness teacher, Farley Murray, by defense Diller. Trial Tr. CPJ-012257 at 3140 .
} 


\section{Good Character ${ }^{267}$}

During the trial, all of Kharey's character witnesses said that Kharey was incapable of such violence. Wise's neighbor when asked of Wise' character during trial said:

There had been a rather spectacular moment that took place at the complex that day where a young man had attempted to commit suicide. And the police had come in to Wise's house to get him and try to keep him from jumping off the terrace. Wise had intervened and went outside, talked to the young man, and grabbed his legs and brought him into the apartment, thereby, you know, not allowing him to commit suicide. ${ }^{268}$

This demonstrated Mr. Wise' decent and peaceful moral character.

\section{vi. Media Frenzy}

The case led to a media frenzy, met with public outcry. The police announced to the press that the teens were part of a gang who were "wilding" while assaulting joggers and bicyclists in Central Park. ${ }^{269}$ When the jury was questioned at voir dire as to whether or not the headlines that they had seen and heard would affect their decision, they each said no, but the possibility that those headlines influenced their decision-making process is obvious. ${ }^{270}$

The effect of the media coverage and the trial sensationalism on the jury was reflected in the trial transcripts: "Defense: Your honor, I have just been looking at the newspaper ... and page one of a newspaper, in very bold headlines, is a story, "Jogger Trial Outburst," and then there is a picture of Kharey Wise ... [t]hen under that, there is, "Defendant Kharey Wise dragged screaming from the courtroom." 271

\section{vii. Failure of Detectives to Investigate Evidence}

\footnotetext{
${ }^{267} \mathrm{Mr}$. Wise is referred alternatively to Kharey and Korey throughout the transcripts. 268 Trial Tr. CPJ-012257 at 2259-3150.

269 BuRns, supra note 16, at 69-70 (claiming "Wolfpack's Prey, Nightmare in Central Park, and Wilding"').

270 Trial Tr. CPJ-009479 at 184-386.

${ }^{271}$ Id. at $184-386$.
} 


\section{and Speak to Other Investigators}

On the night of the jogger getting attacked in the park, Wise stated that he was not in the park but that he was getting a haircut with his friend Eddie LaPaz. The alibi was not investigated by police and was not part of the public narrative on the case. ${ }^{272}$

Kharey made a statement to Detective Hartigan saying that he was never on 102nd cross drive the night of the assault. The defense lawyer stated: "Wise mentioned that they were not with the gang that night and that they were having haircuts, when they spoke about the group last night, you knew what they were speaking about?" and the detective replied with, "Yes I had an idea."273 The defense went on to ask, "What Wise was telling you could constitute as an alibi wouldn't it? Now, did you, offer, convey that information?" and the officer replied with a "No." 274

The investigators did not go to the crime scene until several days after the attack happened. Detective Sheehan questioned Kharey and brought him to the crime scene. Detective Sheehan was not informed about who the other detectives were on the case and was not aware of who questioned Kharey. ${ }^{275}$

When you took him to the crime scene, you took him to where bloodstains were, did you not? The detective answered, yes, sir. He was then asked, And in fact, didn't you ask Wise to dip his hands in the area where the blood was? The detective replied, that never happened, sir. ${ }^{276}$

The late crime scene visits with the defendant tainted the evidence and triggered false confessions.

\section{viii. $\quad$ Conclusion Wise and Richardson}

The Central Park Five is one of the most infamous miscarriages of justice cases. These convictions were based largely on inconsistent false confessions by juveniles. This was not just error; this was misconduct on the parts of police and prosecutors to quickly solve a

\footnotetext{
${ }^{272}$ Trial Tr. CPJ-011343 at 2063-118.

${ }^{273} I d$.

274 Trial Tr. CPJ-012257 at 3140.

${ }^{275} \mathrm{Id}$. at $2259-3150$.

${ }^{276} \mathrm{Id}$.
} 
racially and politically charged case, as the media and public demanded. The canonical factors here included coerced juvenile confessions, racial profiling, poor investigation, poor forensic analysis, overzealous prosecution, tunnel vision, and misconduct. The root sociological causes of the conviction error included racism, justice system culture, the adversarial system, media distortion, and public sensationalism. During an era of high crime and racial stereotype and threat in New York, the structural and contextual causes of the wrongful convictions in this case show that these young men were targeted more because of who they were rather than what they did.

\section{Arizona v. Youngblood ${ }^{277}$}

\section{i. Background}

A review of the transcripts in case of Larry Youngblood's wrongful conviction demonstrate many of the canonical and structural factors found in the cases discussed above. Several well-known routine and structural theories of the wrongful conviction are raised here. These include canonical theories like the inaccuracy related to a juvenile victim's eyewitness identification (raised in Bloodsworth). They also include structural issues such as eyewitness cross-racial misidentification, media coverage regarding a juvenile rape (raised in Bloodsworth), and confirmation bias by jurors who are also parents. The prosecution at voir dire asked whether the jurors who were parents could fairly deliberate on the issues of child kidnapping and sexual molestation. ${ }^{278}$ As explained below, the case also raised issues of forensic malfeasance, rejected by the U.S. Supreme Court. ${ }^{279}$

In October of 1983, a young Latino boy (David) attending a church event was kidnapped by a man and taken to a house in an unknown location where he was raped twice. ${ }^{280} \mathrm{He}$ was returned to the church and immediately brought to the hospital and was later taken

\footnotetext{
277 Larry Youngblood, INNOCENCE PROJECT, https://www.innocenceproject.org/cases/larry-youngblood (last visited Apr. 18, 2020). Coded and written by students at Emily Rookie of Hartwick College and by Melanie Velarde at NVU, Johnson campus. The transcripts cited are Trial Tr. YOUL-003961 at 1-101; Trial Tr. YOUL-004062 at 184-328; and Trial Tr. YOUL004062 at 184-328.

278 Trial Tr. YOUL-003961 at 74.

279 Arizona v. Larry Youngblood, 488 U.S. 51, 57 (1988).

280 Trial Tr. CPJ-012257 at 2259-3150.
} 
in for questioning. He described his assailant as being African American with a bad eye who had short afro-like hair that appeared to be graying. ${ }^{281}$ David later was given the opportunity select from a lineup, from which he chose Larry Youngblood. Youngblood was targeted by police because he had committed a robbery about nine years prior. ${ }^{282} \mathrm{He}$ was convicted and served fifteen years prior to exoneration. He was disqualified from receiving compensation for his wrongful conviction under State law because of his death.

\section{ii. $\quad$ Forensic Malfeasance; No Denial of Due Process}

The case raised important forensic issues related to police tunnel vision and forensic malfeasance regarding the failure to preserve evidence. Youngblood sought damages for a due process violation following his exoneration in the U.S. Supreme Court. He claimed that the police failed to test, preserve evidence and refrigerate the real assailant's T-shirt and the victim's clothing. Had the semen on the shirt been preserved, the evidence would have excluded Youngblood who was a secretor. ${ }^{283}$ The Supreme Court rejected his claim because Youngblood could show no more than negligence and not bad faith. Unless a criminal defendant can show bad faith on the part of the police, failure to preserve potentially useful evidence does not constitute a denial of due process of law. ${ }^{284}$

In this case, the police collected the rectal swab and clothing on the night of the crime; respondent was not taken into custody until six weeks later. The failure of the police to refrigerate the clothing and to perform tests on the semen samples can at worst be described as negligent. None of this information was concealed from respondent at trial, and the evidence-such as it was - was made available to respondent's expert who declined to perform any tests on the samples. The Arizona Court of Appeals noted in its opinion-and we

\footnotetext{
${ }^{281} \mathrm{Id}$.

${ }^{282} \mathrm{Id}$.

283 See Youngblood, 488 U.S. at 51. See generally NORRIS ET AL., supra note 6 (discussing police investigations and the preservation of evidence).

${ }^{284}$ Youngblood, 488 U.S. at 51.
} 
agree - that there was no suggestion of bad faith on the part of the police. It follows, therefore, from what we have said, that there was no violation of the Due Process Clause. ${ }^{285}$

Due to his death, Youngblood was also disqualified from receiving any compensation for his wrongful conviction under Arizona State law.

\section{iii. Witness Misidentification}

The trial transcript raised the issues that the juvenile victim who testified was a poor identifier. The victim had astigmatism, and he was not wearing required glasses the night of the incident. The jury rejected the poor identification and instead was sympathetic to the vulnerability of the child victim. Child victims can make unreliable witnesses due to stress and immaturity. ${ }^{286}$ The child victim testified: "Dave, do you have to wear glasses? Yes, but I didn't have them on that night." 287

Larry's characteristics did not match the victim's description. One reason is that the case involved questionable cross racial identification. The victim was Hispanic, and Larry was African American. The juvenile victim described Youngblood to the detectives as a tall man with black and some gray hairs with a disfigured right eye. The juvenile victim could not recall which of assailant's eyes was bad. ${ }^{288}$ In fact, Larry had a bad left eye. Examine the following identifying statements: "a black man who had . . . a bad right eye."289 "Larry has a bad left eye, not a bad right eye."290 "David was unable to say whether it was the right or left eye . . I simply put some whiteout in the right eye as a random choice." 291 Q: "and you described that man as having a bad or white left eye isn't that right?" A: "Nods head." 292

\footnotetext{
${ }^{285} \mathrm{Id}$. at 58.

${ }^{286}$ NORRIS ET AL., supra note 6, at 26-30.

287 Trial Tr. YOUL-004062 at 102.

${ }^{288} \mathrm{Id}$.

${ }^{289}$ Id. at $196,1.23-24$.

${ }^{290} I d$. at $197,1.4-5$.

${ }^{291} I d$. at $132,1.19-23$.

${ }^{292} I d$.
} 
Risk factors for error in identification were prevalent: ${ }^{293}$ stress on the juvenile victim and cross racial (Hispanic to Black). Stress on the victim at the time of the assault made it difficult for him to correctly identify or rule out the assailant in a lineup. The identification also was cross-racial as Youngblood was Black and the child victim making the identification was Hispanic.

\section{iv. Confirmation Bias of Jurors at Voir Dire}

Larry had been arrested for robbery in the past, and this prejudicial information was revealed to the jury and could have influenced them. Jurors were informed at voir dire: "Larry pled guilty to the crime of robbery approximately nine years ago ... would any of you be more likely to convict Larry merely because he plead guilty to robbery nine years ago?"294 At voir dire, jurors were asked by counsel whether their personal lives/beliefs and family would influence decision. This showed confirmation bias by jurors who were parents. Examining the following question and answer: "you've got children, knowing that David Leon was the same age as your son is now, knowing that the charges are kidnapping, child molestation, and sexual assault, so you think you would have any problems sitting in on the case?" to which the juror replied, "no ma'am."295 This appears to be disingenuous, and persons on the jury who had children the same age as the victim may have been biased.

\section{v. Conclusion - Youngblood}

Transcripts revealed both routine and structural theories of the wrongful conviction in the Youngblood case. These include canonical theories like the inaccuracy related to a juvenile victim's eyewitness

\footnotetext{
${ }^{293}$ NORRIS ET AL., supra note 6, at 26-30 (discussing estimator and system variables). Estimator variables include weapon focus effect, high stress effect and cross racial identification, or another race effect. Id. Curt A. Carlson et al., An Investigation of the Weapon Focus Effect and the Confidence-Accuracy Relationship for Eyewitness Identification, 6 J. APPLIED RsCH. IN MEMORY \& COGNITION 82, 83 (2017); Kenneth A. Deffenbacher et al., A Meta-Analytic Review of the Effects of High Stress on Eyewitness Memory, 28 L. \& HuM. BEHAV. 687, 687 (2004); Gary L. Wells \& E.A. Olson, The Other-Race Effect in Eyewitness Identification - What Do We Do About It?, 7 PsYCH., PUB. POL'Y, \& L. 230, 230 (2001).

${ }^{294}$ Trial Tr. YOUL-003961 at 67-68.

${ }^{295}$ Id. at 74 .
} 
identification and forensic malfeasance. Some of these factors include high stress effect and cross racial identification or another race effect. The factors also include structural issues such as eyewitness crossracial misidentification, media coverage regarding a juvenile rape, and confirmation bias by jurors who are also parents.

\section{Coding Results of the Other Cases}

The remaining cases were coded and briefly summarized in the bulleted list above. These cases fit into the framework of the other wrongful conviction cases with eyewitness identification and false confessions. In addition, the interviews on some of these cases, such as Earl Washington's case, have been conducted and are discussed below. Many of the remaining cases will be the subject of further study and analysis. For example, The Adams/Gray case involved an intellectually disabled female and is another Illinois case which led the Governor of Illinois to suspend the death penalty. ${ }^{296}$

\section{i. Summary of Archival Data}

The Ollins, Bloodsworth, Wise and Richardson (Central Park Five) and Youngblood cases exemplify both the currently recognized causes of error and the root sociological causes of wrongful convictions. The investigation of structural causes using the coding of trial transcripts is unique. While these are well recognized, ${ }^{297}$ the methodology for uncovering them has lagged behind. The coding of transcripts in the above cases reveals deep information about the case and what the jury heard. For example, in their recent study of criminal costs of wrongful convictions and the crimes of true perpetrators, Norris, et al. provided data in Table 2 from the Innocence Project which categorized only four "traditional factors" contributing to wrongful convictions; 1. Eyewitness misidentification; 2. misapplication of forensic science; 3. false confessions; and 4. unreliable informants. ${ }^{298}$ The data is obtained from West and Meterko who cite the main contributing factors associated with Innocence

\footnotetext{
296 Ollins, 2005 WL 730987, at*11. "On October 17, 2002, Governor George Ryan pardoned Calvin Ollins, Larry Ollins, Marcelia Bradford and Omar Saunders based on their actual innocence." Id.

${ }^{297}$ Lofquist, supra note 1, at 19.

${ }^{298}$ NORRIS ET AL., supra note 6, at 6.
} 
Project wrongful convictions as: "misidentification, the misapplication of forensic science, false confessions and use of informants." 299 Other scholars have suggested a holistic approach; "a confluence of factors." 300 The coding of trial transcripts in this study provided additional opportunity to understand structural factors.

Criminologists apply a focal-concerns perspective in evaluating court decision-making. This sociological perspective suggests that "harsher treatment results from stereotypes of racial minorities as more dangerous, more culpable, and less amenable to rehabilitation." 301 This may explain the structural causes of wrongful convictions by police, prosecutors, judges, and jurors here. The perspective suggests that stereotyping may apply to racial minorities like African Americans, Native Americans and Hispanics. The transcripts in these cases revealed that both the canonical list of errors and root sociological causes led to wrongful convictions in these cases, and these categories overlap.

1. False Confessions by Juvenile Defendants and Co-Defendants (Ollins and Richardson/ Wise cases)

After extensive interrogation lasting from fourteen to thirty hours without sleep or nutritious food, confessions were coerced from defendants. The police used techniques of coercion, false promises, deception, and threats. Even though Larry Ollins did not confess, his co-defendants each implicated him in their false confessions. The confessions included fact contamination and narrative contamination and were molded to fit the crime for these particular suspects. ${ }^{302}$ There was deception in the interrogations, which is now inadvisable for

\footnotetext{
${ }^{299}$ West \& Meterko, supra note 4, at 718.

300 Stephanie Roberts Hartung, The Confluence of Factors Doctrine: A Holistic Approach to Wrongful Convictions, 51 SufFolK U. L. REV. 369, 370 (2018). "The coerced and potentially false confession can, in turn, lead to 'tunnel vision'-confirmation bias among law enforcement--causing detectives and forensic analysts to seek out evidence supporting the suspect's guilt, while ignoring evidence that contradicts it." Id.

${ }^{301}$ Spohn, supra note 41, at 20; Darrell Steffensmeier et al., supra note 41, at 778.

302 See, e.g., In re McCray, Richardson, Santana, Wise, and Salaam Litig., 928 F. Supp. 2 d 748 (S.D.N.Y. 2013); Ollins, 2005 WL 730987, at*3.
} 
juveniles. ${ }^{303}$ Investigators lied to each of the defendants to convince them to lie about the others.

\section{Government Misconduct}

Police lied during the interrogation of the juveniles; The prosecution brought the suspects to the scene of the crime; forensic evidence did not match (Ollins case, misleading testimony by State forensic expert Pamela Fish).

3. Misguided and Deceptive Forensic Analysis: Invalidated Forensic Science

Hair and Serological evidence were collected and were no match to defendants (Ollins, Bloodsworth, Youngblood). In Youngblood, police failed to preserve the exculpatory evidence. In Richardson, police brought both defendants to the scene of the crime thus possibly tainting the scene and planting false memories in the defendants' minds before the confessions; defendants' clothing was not taken until after this visit to the crime scene. ${ }^{304}$ In Ollins, state expert Pamela Fish testified that she could not rule out Ollins as one who left the semen at the crime, although, it was not possible for the semen to have been his because he was a secretor. ${ }^{305}$

4. Faulty eyewitness juvenile victim identification, as seen in the Bloodsworth and Youngblood cases.

\section{ii. $\quad$ The Root sociological causes of conviction} error include:

\section{Racism}

Low-income African American and Hispanic males were accused of assaulting a higher-class white female. Police focused on "Blacks and Hispanics" only as seen in the Ollins and Richardson/Wise cases. Throughout the investigation, it was known that the police were searching for "Blacks and Hispanics," and they focused their search on

${ }^{303}$ Kassin, supra note 52.

${ }^{304}$ Trial Tr. CPJ-012257 at 3140; BURNS, supra note 16, at 52.

305 Trial Tr. OLL-000598. 
the projects. The media used animalistic and racist terms to describe the defendants; the hair evidence was "like" Richardson's hair. Police may be more easily convinced of a suspect's guilt when it conforms to their race expectations and stereotypes. ${ }^{306}$

\section{Justice System Culture}

Instead of "innocent until proven guilty," the justice system deemed these defendants guilty and wove a narrative around that premise. The prosecutorial team was on the same team with the police rather than the side of actual justice as seen in the Ollins and Bloodsworth cases.

\section{Behavior of Immature Accused}

The use of deceptive interviewing was not appropriate for juveniles as seen in the Ollins and Richardson/Wise cases. It is irresponsible to expect young people to understand Miranda warnings or to understand that any statement they give can be used against them. Youth of Accused: Wise, Richardson, and Ollins were fourteen and sixteen years old. All had some form of learning disability; while Wise may have been sixteen physically, intellectually, he was only approximately twelve years old, and he did not have a parent, guardian, or any family member present. The two sixteen-year-olds were old enough to be considered adults, but they were too young to be considered for the death penalty.

\section{Law Enforcement Displayed Confirmation Bias, Hindsight Bias, and Tunnel Vision, As Seen in the Ollins, Richardson/Wise and Bloodsworth Cases.}

Confirmation bias is the source of most of the factors (traditional and root) leading to wrongful convictions. "Generally, confirmation bias refers to the tendency to seek, recall, and interpret information that supports, rather than refutes an existing belief." Tunnel vision is

306 O'BRIEN \& FINDLEY, supra note 2, at 36, 37; Taslitz, supra note 49, at 126 ("There is ample data showing that whites generally believe that African-Americans are more violent than whites."). 
defined as, "The inability of a police or prosecutor to properly credit exculpatory information when they already are convinced of a suspect guilt." 307 In Richardson/Wise, once the police and prosecutorial team focused on the defendants, they did not pursue any other leads or follow through with any forensic evidence. They ignored a true and obvious suspect, Matias Reyes. ${ }^{308}$ The police and prosecutors continued to pursue these suspects even when it was determined they may not have done the crime. ${ }^{309}$ Kevin Richardson was struck by an officer while being apprehended, but this was used to show guilt.

\section{Ineffective defense attorney representation}

Defense attorney independent investigations should have taken place regarding evidence and the crime scene. A character witness was presented for Kevin Richardson, but it was never brought into evidence that Richardson was learning disabled. Kharey Wise was hearing impaired and learning disabled. He had saved a neighbor's life, but these character factors were not raised. These factors are seen in the similarities of the Roscetti Four, ${ }^{310}$ Central Park Five, ${ }^{311}$ and other cases.

\section{E. Interviews ${ }^{312}$}

In conducting each interview, the students used both their experience and depth in coding the trial transcripts and cases and their

\footnotetext{
307 O'BRIEN \& FINDLEY, supra note 2, at 36.

${ }^{308}$ BURNS, supra note 16, at 27, 114-23. In the Central Park five cases (Richardson), the forensic evidence brought against the five juveniles was inaccurate. The absence of parents and guardians during interrogations lead to some false confessions. Legal representation was not present either. This led to the juveniles to falsely accuse one another. Id.

309 O'BRIEN \& FINDLEY, supra note 2, at 36; Ollins, 2005 WL 730987, at *1-4; Larry Youngblood, supra note 277.

${ }^{310}$ See Ollins, 2005 WL 730987, at *3-4.

311 In re McCray, 928 F. Supp. 2d at 748.

312 The following interviews were conducted by the student researchers: Interview by Alyasha Walker \& Kiley Richardson with Barry Weinstein, Clemency Att'y for Earl Wash., at Hartwick Coll. in Oneonta, N.Y. (May 2017); Interview by Sheryl Hugh with Vanessa Meterko, Researcher for the Innocence Project, at Hartwick Coll. in Oneonta, N.Y. (May 2017); Interview by Debra Fulton with Sen. Patrick Leahy, U.S. Senator for the State of Vermont, at N.V.U., Johnson campus (Nov. 2017);
} 
analysis of the structural reasons explaining wrongful convictions in the interviews. They pressed the interviewees to give insight into the causes and remedies for wrongful convictions. The structured interviews culminated the research project permitting the interviewers and the subjects to think deeply on the topics. Barry Weinstein was personally involved in the Earl Washington case and provided a personal perspective on the confessions and the post exoneration reentry. Vanessa Meterko worked with The Innocence Project to compile data on the cases studied. The lawmakers, Patrick Leahy and Joe Benning have brought real reform through legislation. Finally, the most compelling interview with a prosecutor, P.F., has shown the possibility of issues of tunnel vision and confirmation bias among law enforcement. Perhaps the interview style of Tonya and Fadhili was the most persistent and strongest in bringing out structural issues that lay between the lines for law enforcement.

\section{i. Barry Weinstein}

Barry Weinstein and Eric Freedman were two of the postconviction defense attorneys for Earl Washington during his wrongful conviction and clemency appeals. ${ }^{313}$ Washington (African American) was wrongfully sentenced to death and served seventeen years in prison in Virginia after providing a coerced confession for the murder of Rebecca Williams (white female) in 1982, after prolonged interrogation. He has an IQ of sixty-nine and was twenty-two when arrested. His personality and intellectual disability caused him to try to please the law enforcement interrogators. ${ }^{314}$ His original trial was very short, and the most information is found in two clemency petitions from 1994 and 2000, filed by Weinstein, who also obtained a stay within days of Washington's pending execution.

Interview by Tonya Kendall \& Fadhili Achinda with P.F., L. Cnty. State Prosecutor, at NVU, Johnson campus (May 2018) (since the interview includes editorial commentary about prosecutors, the prosecutor is identified by initials to protect confidentiality). Interview by Amber Burke \& Courtney Currier with Sen. Joseph Benning, Vermont State Senator for the Caledonia District, at NVU, Johnson campus (May 2018).

313 Interview with Barry Weinstein, Clemency Attorney for Earl Washington, in Milton, Mass. (2019). Mr. Weinstein was interviewed again by students at Curry College, who are Boston City Police Officers.

314 Freedman, supra note 77, at 1095, 1105. 
Weinstein told the interviewers that when he took over the case upon moving to Virginia to provide capital defense, he knew immediately that Washington was innocent due to the errors in the case. These included "misleading evidence, official misconduct, inadequate preparation of attorney and sloppy work." 315 Weinstein spent two and a half decades working on behalf of Washington. He was the closest of the attorneys to Washington. Washington called Weinstein weekly, and Weinstein visited him every other week. After Washington served more than seventeen years in prison, Weinstein also worked to help Washington return to the community and established a trust fund from a wrongful execution award.

The interviewers asked Weinstein "What were your thoughts about intellectually disabled people being convicted? Should they have different treatment in court?" 316 Weinstein responded that an intellectually disabled person lacks understanding of the proceedings and the questions, especially for a complex death case. In this case, the jury was never told that Washington was intellectually disabled. The interviewers asked what kept Washington going during the seventeen years behind bars? Weinstein replied, "Hope." ${ }^{17}$ After his release and exoneration, he was finally a free man, got married, got a job, and received two million dollars in a trust for the wrongful conviction. But "he can never get those years back." 318 He is fiftyseven years old, and the trust fund will help support him for life. The opportunity to interview an attorney who heroically took on the case and saved his client's life was very exciting for the students. They finally focused on the problem of wrongful convictions and what could be done to solve them. Did this conviction involve: lack of adolescent competence, racial profiling, poor investigation, or tunnel vision? "What should be done about this problem of wrongful convictions?"319 What do you think was the reason for this wrongful conviction? ${ }^{320}$ The answers were profoundly moving about the need for a competent defense and prosecution misconduct. The students appreciated Weinstein's openness and willingness to speak to them.

\footnotetext{
${ }^{315}$ Interview with Barry Weinstein, supra note 313; Interview with Barry Weinstein, supra note 312.

${ }^{316}$ Interview with Barry Weinstein, supra note 313.

${ }^{317} \mathrm{Id}$.

${ }^{318} \mathrm{Id}$.

${ }^{319} \mathrm{Id}$.

${ }^{320} I d$.
} 


\section{ii. $\quad$ Vanessa Meterko}

Vanessa Meterko is the Senior Research Analyst at The Innocence Project. ${ }^{321}$ Interviewer Sheryl Hugh took the Salaam wrongful conviction case as a very personal explanation of the structural racism component in wrongful convictions, and it is easy to agree with her. Ms. Hugh is now a graduate student for her MSW at NYU and a Social Work intern. Ms. Hugh concluded that the interview helped her contextualize her theories on the criminalization of Black males in law and practice. The questions were designed to elicit these contextualization theories. ${ }^{322}$

The interviewer initially asked about Meterko's reactions to the general process and the outcome of the Central Park Five cases and to the case of Yusef Salaam. ${ }^{323}$ Meterko stated that she was most struck by the youth of the wrongfully convicted. ${ }^{324}$ When she saw Kharey Wise in the Sarah Burns film, she realized that at age sixteen he looked like a small child. Meterko stated that she became familiar with wrongful convictions when she focused on the Marty Tankleff case ${ }^{325}$ in her graduate course. ${ }^{326}$ This early education, she stated, "around the phenomenon of false confession made it really easy for me to see that it was completely plausible for Yusef Salaam . . . to be pressured into confessing . . . ."327 The interviewer asked Meterko, based on her knowledge of the Central Park case, what she believed were the "practices, ideologies, and processes that led to this outcome?" Meterko thoughtfully answered, "As with any wrongful conviction case there are a whole lot of factors at play and . . . they're all influencing one another ...." She specifically mentioned, "[t]he press and culture in New York at the time." ${ }^{328}$ Moreover, Meterko stated:

${ }^{321}$ Interview with Vanessa Meterko, Researcher for the Innocence Project, in Milton, Mass (2019). Ms. Meterko was interviewed again by students at Curry College, who are Boston City Police Officers.

${ }^{322}$ Interview with Vanessa Meterko, supra note 312.

${ }^{323}$ In May 2017, Sheryl Hugh and her student research group at Hartwick College interviewed Ms. Meterko from the Innocence Project. Sheryl Hugh had coded the trial transcripts for Central Park Five accused Yusef Salaam and her questions focused intensely on this case.

${ }^{324}$ Interview with Vanessa Meterko, supra note 312.

325 Marty Tankleff, A True Story of a False Confession, https://www.martytankleff.org/the-story (last visited July 1, 2020).

${ }^{326}$ Interview with Vanessa Meterko, supra note 312.

${ }^{327} I d$.

${ }^{328} I d$. 
I think one other interesting aspect to this case is the resistance to exculpatory evidence ... DNA testing that excluded them from some of the physical evidence in this case and that was kind of disregarded and explained away ... they thought there was a sixth person, but just assumed they did not catch him and that convicting five was good enough. They can override that physical evidence . . . to fit the evidence to their theory. ${ }^{329}$

Meterko commented that she believes that race is a major factor in many wrongful conviction cases and that we cannot disregard the "presumption of criminality for Black male teens and adults in the US."

Hugh concluded the interview by asking a series of questions regarding Meterko's opinion on law enforcement and prosecutor's role in wrongful convictions. This included questions such as: what steps police could take to avert the consequences of tunnel vision expectations about a case; if there were consequences for law enforcement and prosecutors whose mistakes and misconduct lead to wrongful convictions; and how can we reduce the effects of police racial bias and coercive interrogations? Meterko responded that it is "hard to check ourselves." 330 One solution would be for law enforcement to designate someone as an ombudsman and official devil's advocate who can check out the possibility for errors. It is important to have an alternate view of things. Further, there should be more training programs. With regard to the interrogation of juveniles, Meterko said that juveniles often do not understand the language or concept of Miranda warnings because they feel they are innocent, they feel they have nothing to hide. ${ }^{331}$ Her advice is that juveniles should be silent when not accompanied by lawyers or even parents. There should be better practices to ensure the protection of juveniles in interrogation. ${ }^{332}$

In summary, the interviewer surmised that her research coding the Salaam transcripts and her interview with Meterko led her to recognize how "social construction of race, class and gender" were all

\footnotetext{
${ }^{329} I d$.

${ }^{330} \mathrm{Id}$.

${ }^{331} I d$.

${ }^{332} I d$.
} 
significant components in Salaam's case. The interview showed how students combined personal experiences in their lives with aspects of their research. ${ }^{333}$

\section{iii. $\quad$ U.S. Sen. Patrick Leahy}

U.S. Senator Patrick Leahy of Vermont was interviewed by Debra Fulton via written questions and response on November 9, 2017. ${ }^{334}$ The student interview revealed many responses regarding how to improve the criminal justice system to encourage exonerations. Senator Leahy discussed his sponsorship of several important criminal justice initiatives, the Kirk Bloodsworth Post-Conviction DNA Testing Grant Program under the Innocence Protection Act, the Justice for All Reauthorization Act, signed into law by President Obama on December 2, 2016, and the Second Chance Act. ${ }^{335}$ The Senator was careful also to mention legislation regarding the rights of victims and the opportunity for crime labs to obtain funding. Because the interviewer had researched trial transcripts in the Ollins, Wise, and Bloodsworth cases, the interview questions regarding the Senator's support of these innocence initiatives and the responses were particularly relevant. ${ }^{336}$

The interviewer asked the Senator whether he was directly involved in the Kirk Bloodsworth exoneration case. The Senator stated that he was not involved with the investigation or court proceedings involving Bloodsworth. However, as a result of his case, he stated, "I worked to author and enact the Kirk Bloodsworth PostConviction DNA Testing Grant Program, under the Innocence Protection Act." He stated that the program authorizes federal grants for states to provide testing in cases where a defendant has been convicted, but key DNA evidence was not tested. Bloodsworth was the first person in the United States to be exonerated from a crime while sitting on death row through DNA evidence. ${ }^{337}$

The interviewer then discussed how it could be easier for an innocent person to have their case reviewed and, overall, for a person claiming innocence not to have to spend years in prison pending

\footnotetext{
${ }^{333} \mathrm{Id}$.

${ }^{334}$ Interview with Sen. Patrick Leahy, supra note 312.

${ }^{335} I d$.

${ }^{336} \mathrm{Id}$.

${ }^{337} I d$.
} 
exoneration. ${ }^{338}$ The Senator explained that the Innocence Protection Act, and specifically the Kirk Bloodsworth Post-Conviction DNA Testing Program, provides grants to states to test DNA evidence that has not been evaluated. According to Senator Leahy, in capital cases and other serious felony cases where DNA evidence is not conclusive, each side must have adequate, competent, and well-trained counsel. The Innocence Protection Act includes the Capital Representation and Prosecution Improvement Grants to train counsel in capital cases where there otherwise would not have been any resources for training. He also discussed his role in passing the Justice for All Reauthorization Act, which reauthorized the Paul Coverdell Forensic Sciences Improvement Grants last year. ${ }^{339}$ The Grants provide critical funding to state and local labs to improve the quality and timeliness of forensic science and medical examiner services. These funds help eliminate backlogs in the analysis of forensic evidence.

Senator Leahy also described the role of the Justice for All Reauthorization Act to assist both crime victims and potential exonerees in Federal Court. ${ }^{340}$ The Justice for All Reauthorization Act was signed into law by President Obama on December 2, 2016. The Act allows federal post-conviction DNA testing, even for people who waived their right to such testing, given that nineteen of the first 250 individuals exonerated by DNA evidence waived their rights and pleaded guilty despite their innocence. It also gives federal judges more flexibility to grant a new trial or sentence when exculpatory DNA evidence is discovered. Still, more must be done. The law renews the Innocence Protection Act and the Kirk Bloodsworth Post-Conviction DNA Testing Grant Program by supporting grant programs that fund forensic testing, intending to reduce rape kit backlog. The Act requires the Justice Department to assist state and local governments to improve their indigent defense systems and ensures implementation of the Prison Rape Elimination Act. Additionally, the Act makes it easier for crime victims to assert their legal rights and maintains funding for programs that notify victims of their rights and provide assistance.

Senator Leahy concluded that it is never easy to get important legislation through both the Senate and the House and signed by the President. The Kirk Bloodsworth Post-Conviction DNA Testing Grant Program, under the Innocence Protection Act and the Justice for All 
Reauthorization Act, were difficult to pass, but they were the right thing to do. The Senator indicated that he worked across the aisle with his Republican colleagues to help make our justice system a bit more just. It required bipartisan support. ${ }^{341}$

The interviewer summarized her experience, stating, "I am thankful that even though wrongful convictions are still occurring, efforts are in place to stop them, and I'm grateful that Senator Leahy has done so much for those efforts."

\section{iv. $\quad$ State Sen. Joseph Benning}

Student researchers Amber Burke and Courtney Currier gained a local perspective through their interview of State Senator Joseph Benning of Caledonia County, Vermont, who formerly served as an assigned defense lawyer. ${ }^{342}$ (Ms. Burke recently graduated in 2021 from New England Law School in Boston). The interview goals were to explore his opinion on issues within the criminal justice system and learn about his views on wrongful convictions, which would have a Vermont spin.

As a youth in high school, Senator Benning was wrongfully accused of marijuana possession. ${ }^{343}$ According to the Senator, this experience stimulated his interest in the law and eventually in wrongful convictions. ${ }^{344}$ The interviewers turned Senator Benning's attention to his experience with any wrongful convictions that have occurred in Vermont.

Senator Benning surprisingly indicated that he was not aware of any significant exonerations in Vermont. But, he recounted, "Very early in my career, there was a police officer who got busted for planting evidence in drug cases. So, there were a string of individuals who had been wrongfully convicted." 345 This experience prompted Senator Benning to distinguish between cases where a person was innocent and cases where the state failed to provide the evidence to prove the case. He reported that he had been involved in many cases that the State had not proven their case or were thrown out for one

\footnotetext{
${ }^{341}$ Id.

${ }^{342}$ Interview with Sen. Joseph Benning, supra note 312.

${ }^{343} I d$. (according to Benning, "[h]e was hanging out with a group of boys, playing music, growing out their hair long, and doing what youth were doing in the 1970s."). ${ }^{344} I d$.

${ }^{345} I d$.
} 
technicality or another, but he fell short of stating the person was factually innocent. Instead, he stated, "I cannot think of anyone who has been exonerated on DNA that it was absolutely impossible for them to have been the perpetrator." 346 But the Senator immediately recalled his experience with the well-known wrongful conviction case of Ronald Cotton and shared the story with the interviewers. ${ }^{347}$

The interviewers were familiar with the eyewitness identification case involving Ronald Cotton, having learned about the case during this course and that eyewitness misidentification has proven to be an unreliable form of evidence. They asked Senator Benning what circumstances could affect a witness's credibility at trial? "The first thing a defense attorney looks for is any motive [from] a complaining witness as to why they would want to get my client in trouble." 348 Using an example of a domestic assault charge that coincided with a custody battle, the Senator explained, "There might be motive on the part of one person to be exaggerating what happened to them during some kind of dispute, to gain an advantage in the custody battle." He also felt that "there are situations where people are just unreliable because they were viewing something and it was a momentary view, which was compounded by seeing someone that looked like the perpetrator shortly [after that] . . they misidentify." 349

The interviewers continued the interview by exploring systemic issues that lead to wrongful convictions in the United States (e.g., false confessions, plea bargaining, war on drugs). The

\footnotetext{
${ }^{346} I d$.

${ }^{347} I d$.

I will tell you, however, that my judiciary committee - I am the senate chair of the judiciary committee - about a year ago we all became familiar with a case. They made a book out of it called Picking CotTON. There was a woman who had been raped and had been - essentially been given a lineup of black men that she was told to look over and decide if the alleged rapist was in that group. She picked a guy named Cotton. Well, we spoke to her and we spoke to him. It was all incredibly fascinating. It was clearly a situation of misidentification. So, we are very familiar with the subject, and as a result of that, we were addressing how to make changes to the law to make sure people are not wrongfully convicted. The human animal is capable of making mistakes. Science is capable of making mistakes. So it is one of those things that will always be with us, and we always have to be on our guard so that people are not wrongfully convicted.

Id.

${ }^{348} I d$.

${ }^{349} I d$.
} 
interviewers asked Senator Benning what factors might lead to somebody falsely admitting to a crime. "It is not an uncommon tactic for police to put an individual in a terrible situation to extract some kind of a statement from them." 350 The Senator told the interviewers of a local story where officers charged an individual with twenty-nine burglaries, where there was not always evidence that a burglary occurred. ${ }^{351}$ He stated that the officers tell the suspect, "Yeah, yeah, yeah, we'll let you go if you confess to XY[Z]." ${ }^{352}$ Senator Benning told the interviewers that it is not uncommon for law officials to hold suspects in jail and threaten them with the continued loss of visitation with their children. He stated, "You can let your imagination run wild, on what situations would convince a person to say, 'I just want to get out of here and go home, so I'll say what they wanna hear and get outta here.' And that happens a lot." 353 Senator Benning mentioned that "it's up to the police how they treat somebody if they can extract a confession that's not a true confession just an exasperation of trying to get out of the situation they are immediately in and back to something familiar." 354

The interviewers asked about the role of plea bargains in the criminal justice system. Plea bargains might even convince a person to confess to a crime they did not commit. This phenomenon is evident with the War on Drugs tactics of intimidating and forcing individuals into confessing to crimes for fear of not fighting the case for lack of resources or knowledge of the courts. From the Senator's experience, he stated:

A lot of times, you will see a felony charge brought, and a misdemeanor charge brought on the same offense. So, let's say somebody has a burglary charge and petty larceny charge in the same information. . . The prosecutor knows this is a first offense situation. The likelihood of someone getting convicted on the burglary will have some hole in it, but they bring that knowing they want to get a good conviction on petty

\footnotetext{
${ }^{350} I d$.

${ }^{351} I d$. According to the Senator, many of the "so-called" burglaries were situations where "somebody found their back screen door cracked open, they reported that to the police at the time, and the police marked it down as a potential burglary." Id.

$352 \mathrm{Id}$.

${ }^{353} \mathrm{Id}$.

${ }^{354} I d$.
} 
larceny. So the plea bargain forces the defendant to take a choice. . . . From the defensive position, it puts you in the corner where you have to say to your client, look, you can roll the dice and try to go to trial still. The chances are you're going to get convicted on something, and if they convict you on the felony, we can't rule out the possibility of jail time. [F]rom a defense perspective [it] is kind of frustrating because you are, sort of, backed into a corner of having to deal, as opposed to [questioning if] this a weak case. When you might [typically] take something to trial, your defendant might not want to take that chance. Now, from the [S]tate of Vermont's perspective, if you have the opportunity to plea bargain cases, the chances of you getting a conviction are raised because you have [fewer] people going to trial. In the court's perspective, that means that you are not spending a whole lot of money on jury trials and in the courthouse. ${ }^{355}$

In conclusion, the interviewers asked Senator Benning about what criminal justice reforms he would suggest or has supported in the past that might address wrongful convictions as a whole. He reflected on his personal experience with false accusation as a teenager and the significance it plays in his Senatorial role today:

When I got into the legislature in Vermont, the state did not have an expungement process. So, the very first bill I signed my name onto was for the expungement process. We have had great success with that. A lot of people have gone through and cleaned up their old records. We are continuing to improve that so that if you are convicted of something in this day in age, and it's no longer a crime, for instance, possession of a small amount of marijuana, in VT, now you can automatically have that expunged without having to petition the court to have that happen. It's an ongoing process of criminal justice reform. I'm very proud to be part of that. ${ }^{356}$

\footnotetext{
${ }^{355} \mathrm{Id}$.

${ }^{356} \mathrm{Id}$.
}

When I was charged with my marijuana offense back in 1975, they did not bring a charge against me. They dismissed it before I was arraigned, 
Senator Benning stated that the Vermont Senate is currently reviewing statutes that "no longer make sense" to try to figure out "what things can be changed, to free up valuable resources." 357 Senator Benning stated that he is constantly looking to reform the system for the modern age. ${ }^{358}$

The interviewers expressed their gratitude for lawmakers like State Senator Joe Benning and U.S. Senator Patrick Leahy. They are willing to push through significant justice reforms to create a justice system that makes more sense.

$$
\text { P. F. }{ }^{359}
$$

In May of 2017, at the NVU Johnson campus, students Tonya Kendall and Fadhili Achinda interviewed the L. County State Attorney, P. F., who has been a prosecutor for thirty-five years. ${ }^{360}$ The interviewer noted that it is essential to understand the mindset of a person whose role it is to "promote justice to the entire community, including those people charged with crimes." 361 The purpose of interviewing F. is to take a deeper look at how the prosecutor's views

\footnotetext{
but I had a record. New Jersey -this is where I'm from - at the time had an expungement process. So that somebody in my situation could have their record erased.

Id.

${ }^{357} I d$.

We also have many different criminal laws out there that are constantly being looked at to determine whether or not if they should continue with the level of penalty that they have had for a number of years. Some things no longer make sense and we are reviewing the statutes to figure out what things can be changed, to free up valuable resources. One of those things is driving with a suspended license. When I first started practicing that was automatically a criminal offense, and it got so bad that during the 1990 's virtually my entire caseload was DLS cases. The problem was that people couldn't afford the fees to get reinstated. One reform was to drop the criminal charges to a civil offense. They also had arrangements so you could get your license on a payment plan, where normally you would have had to pay the entire thing up front. Not only would you get your license back but you also wouldn't get stopped again and cited once more for DLS.

Id.

${ }^{358} I d$.

359 The interviewee's initials are used to protect the confidentiality.

${ }^{360}$ Interview with P.F., supra note 312.

361 Bennett L. Gershman, The Prosecutor's Contribution to Wrongful Convictions 109 (Allison D. Redlich et al. eds., 2014).
} 
of arrest, crime, and wrongful convictions affect decision-making. The interviewers theorized that a prosecutor would have a crime control perspective on the idea of error. In fact, F. looked at the incidence of wrongful convictions confined to states like Louisiana and not Vermont. The interviewer concludes that the idea that the criminal justice system was fallible came late to officials and judges. It is time that prosecutors, especially, accept this undeniable fallibility and understand the prevalence and impact of wrongful convictions on our justice system. This is important considering that scholar Susan Bandes states that one problem occurring in nearly all erroneous convictions is "the refusal of prosecutors to concede that the wrong person was convicted, even after defendant's exoneration." 362

The questioning began with whether $F$. felt wrongful convictions were a frequent and recurring problem. ${ }^{363}$ In many prosecution jurisdictions, there are conviction integrity units to correct and avoid wrongful convictions, including the Manhattan District Attorney. ${ }^{364}$ However, F. answered, without authority, that only a small percentage of persons are wrongfully convicted in Vermont and nationwide overall. Noticing an element of denial from the prosecutor, the interviewer brings to F.'s attention that some experts suggest that there are currently twenty thousand innocent persons currently incarcerated. ${ }^{365}$ Then, F. is asked, "If this is true, what kind of control does he think should be in place to prevent one more wrongful conviction?" F. replied, "I was reading an article about the issues that are happening in Louisiana with underfunding of the public defenders, so you know the more resources we provide for, the more fair just outcomes." ${ }^{366}$ F. maintained his steadfast belief that those who have been convicted are guilty. The interviewer thought the phrase 'only the guilty are convicted' certainty was confirmed when he said that the

\footnotetext{
${ }^{362}$ Susan A. Bandes, Loyalty to One's Convictions: The Prosecutor and Tunnel Vision, 49 How. L. J. 475, 475 (2006).

${ }^{363}$ Interview with P.F., supra note 312.

364 John Eligon, Prosecutor in Manhattan Will Monitor Convictions, N.Y. TIMES (Mar. 4, 2010), https://www.nytimes.com/2010/03/05/nyregion/05wrongful.html; Press Release, Cyrus R. Vance, District Attorney, Announces Conviction Integrity Program (Mar. 4, 2010), https://www.manhattanda.org/district-attorney-vanceannounces-conviction-integrity-program.

${ }^{365}$ Robert J. Ramsey \& James Frank, Wrongful Conviction: Perceptions of Criminal Justice Professionals Regarding the Frequency of Wrongful Conviction and the Extent of System Errors, 53 CRIME \& DELINQ. 436, 440 (2007).

${ }^{366}$ Interview with P.F., supra note 312.
} 
system could "probably provide more resources, but . . . if people are fairly convicted and their appeal is upheld . . . I think . . you have people who go to jail who are rightly convicted but ... they don't want to admit that they did it, so they insist they were wrongly convicted . . . ." The interviewer cites O'Brien and Findley on prosecutors' confirmation bias. "A prosecutor whose case resulted in conviction and was affirmed on appeal may become even more convinced of its legitimacy and thus especially unreceptive to evidence suggesting innocence." $" 367$

Next, the interviewer raised the issue of what is a prosecutor's perspective on no crime cases. "According to the National Registry of Exonerations, of the first 2,018 cases, one-third of them are categorized as a no crime case. From the perspective of a criminal justice actor, how do you think this happens?"368 The prosecutor responded:

You know my victims' advocate would dispute that such an event will ever happen.... You can look at that and say there is no crime because the complaining witness recanted, or you could say, what I know about domestic violence cases is that it probably did happen but the person recanting because they were looking at the long term future of the relationship and not at the particular incident. ${ }^{369}$

The interviewer concluded that a prosecutor with a mindset that every defendant taken to trial is guilty would be apt to believe that no crime cases do not exist.

The interview then turned to racial bias as a factor in wrongful convictions. The interviewer asked the difficult question about what the prosecutor thought about racial equity. " $62 \%$ of DNA exonerees are African American. How big a role do you think race places in our criminal justice system? What do you think can be done to identify areas of potential racism or bias that lead detectives from having tunnel vision?"370 First, the prosecutor agreed that race did play somewhat of a role in Vermont when he states, "[n]on-white people in jail in Vermont are a higher percentage of the inmate population than in the

367 O'BRIEN \& FINDLEY, supra note 2, at 40.

${ }^{368}$ Interview with P.F., supra note 312.

${ }^{369} \mathrm{Id}$.

${ }^{370} I d$. 
population at large."371 But then he says, "I would like to think that most criminal investigators start out with an open mind. But when you think about stereotypes, it is like, the reason that stereotypes exist." 372 Nevertheless, F. blamed the sales of New York City drugs in Vermont for high prices as one reason for racial disparities. He clearly felt there was a bias in favor of local white persons getting rehabilitation, and persons from New York City getting punishment based on his following statement:

Many of the people, not all, ... who are engaged in drug activity are inner city people from New York City. They stand out in a state like Vermont. If you arrest someone from New York City on a drug charge and it comes time to sentence them, you are not going to put them on probation because they are not part of the community.... A person from Vermont ... okay you should go to jail for a while and they go on probation and we will get you treatment and we'll monitor your behavior. If you are from the Bronx and you are just in it for the money, we really don't want to encourage people to establish roots in the community. ${ }^{373}$

This bias in favor of treatment for local white community members shows a fear of outsiders and crime coming in from New York. It is probably common to the criminal justice system. Based on F.'s statements, rehabilitation is reserved for local Vermont residents (who are mostly white). It is not considered for persons who are not a part of the community, who are punished. Vermont's population is fairly homogeneous; in fact, probationer populations are overwhelmingly white, which is representative of Vermont as a whole. ${ }^{374}$ Thus, members of racial and ethnic minority groups may also experience outsider bias in the criminal and restorative justice processes.

Yet, F. acknowledges that once the disparity in the data is exposed, there can be a conversation about how to prevent it from

\footnotetext{
${ }^{371} I d$.

${ }^{372} I d$.

${ }^{373} \mathrm{Id}$.

374 David R. Karp \& Kevin M. Drakulich, Minor Crime in a Quaint Setting: Practices, Outcomes, and Limits of Vermont Reparative Probation Boards, 3 CRIMINOLOGY \& PUB. POL'Y 655, 664 (2004); Leona Jochnowitz, Book Review, 56 CRIM. L. BULL. (2020).
} 
happening. ${ }^{375}$ The interviewer concludes that F.'s words denote bias, "although I am sure he would deny this. . . . Tunnel vision begins with the initial stages of the criminal justice process when the individual has the first contact with law enforcement . . ." 376 But, Findley \& Scott assert that "the later stages feed off the information generated in the police investigation." 377

The interviewer perceptively asked about the pressures of the adversarial system to obtain a conviction. Do you feel the importance of a win for the prosecution often comes at a cost to actual justice? Do you have any suggestions on how to get a prosecution team out of that "must-win" mindset? F. responded that there is pressure on law enforcement and elected officials to keep the peace and bring unsolved cases to closure. The interviewer commented that the interviewee is quite a storyteller, each tale giving insight into his beliefs that "most violence coming into Vermont is from "others" who carry with them their violent culture . ..."378

The interviewer then asked about official misconduct based on the Ollins case, discussed above, which she researched. She referenced the false testimony by the forensic expert in that case. Pamela Fish, the forensic expert, lied about the secretor evidence, and the hair evidence was unreliable. ${ }^{379}$ The same analyst provided false testimony in three other trials, also leading to a wrongful conviction. "What are your thoughts as to what punishment should come to those involved in misconduct like coerced interrogations that leads to a wrongful conviction?"380 The interviewer cites the literature that "a prosecutor who questions the integrity of a police investigation risks straining that relationship." 381 F. response, without authority, is that misconduct is very rare. ${ }^{382}$

On the issue of preventing false confessions, F. was asked: "[n]early half of the exonerations in 2016 resulted from false admissions. Why do you think people false confess? What policies do you think can be implemented that can help identify or prevent false confessions?" The interviewer persists: "[s]o you don't think during

\footnotetext{
${ }^{375}$ Interview with P.F., supra note 312.

${ }^{376} \mathrm{Id}$.

${ }^{377}$ Findley \& Scott, supra note 188.

${ }^{378}$ Interview with P.F., supra note 312.

379 Ollins, 2005 WL 730987, at *1, *3.

${ }^{380} I d$.

${ }^{381}$ O'BRIEN \& FINDLEY, supra note 2.

${ }^{382}$ Interview with P.F., supra note 312.
} 
the investigation process, there is any responsibility of law enforcement to look further into this testimony? ${ }^{383}$ F. tries to explain why someone would falsely confess as a matter of his self-benefit, not misconduct. The interviewer maintains that $\mathrm{F}$. has very strong beliefs that the guilty are guilty and that the only reason they would say they were not was if they had ulterior motives to do so. And, he tries to reduce his cognitive dissonance by convincing himself he is doing the 'guilty' defendant a favor by offering a plea bargain or by placing the wrongful conviction issue with the jury.

The interviewer persisted on uncovering the prosecutor's views on wrongful convictions and found that many of the structural causes of these errors persist including tunnel vision and confirmation bias. She cited the literature on prosecutorial conduct. ${ }^{384}$ Perhaps the most important question was whether the prosecutor was willing to apologize to persons who had been wrongfully convicted. Here the prosecutor showed a sense of truthfulness and ethics, indicating he would apologize for mistakes. "Many exonerees desire an apology from government officials, or at least an acknowledgement of the errors that led to their suffering. What are your thoughts on apologizing to an exoneration?" 385 F. replied,

Yes. I think I would. My job is to review the evidence in the cases that police are investigating and decide whether or not to charge them. My decision is based on whether I believe there is enough admissible evidence to convince twelve people beyond a reasonable doubt that they are guilty. So, if someone came back, who I had convicted and who had been exonerated, I think that would be very difficult as a professional who takes pride in my work to accept that. ${ }^{386}$

He cites his personal history as a defense attorney.

In summary, this insightful interview with the prosecutor uncovered many potentially root sociological causes of errors including the adversary system, confirmation bias and possible racial profiling. The interview is probing and persistent. "There is no doubt that he holds strong beliefs that anyone convicted of a crime must be

${ }^{383} \mathrm{Id}$.

${ }^{384} I d$. (citing O’BRIEN \& FINDLEY, supra note 2).

${ }^{385} \mathrm{Id}$.

${ }^{386} I d$. 
guilty." 387 Yet, his willingness to apologize offers some hope to selfacknowledgement and reform.

\section{F. Results of Interviews}

Interview results of professionals, whether directly involved with the case or professional researchers, prosecutors, defense lawyers, and public officials, add insight into the public attitudes of wrongful convictions. The same issues found in the archival data-false confessions, mistaken eyewitness identification, tunnel vision, racism, and law enforcement misconduct - arose within these conversations. Some of the interviewees were reformers who acknowledge the problems, and others were law enforcement who turned a blind eye to the need for reforms or the existence of problems. In a way, the representatives of the system, defense, prosecution, research and legislation explained the structural and cultural aspects of the justice system based on their own experiences. For example, the prosecutor F. tried to explain why someone would falsely confess as a matter of his self-benefit, not misconduct. The guilty are guilty and that the only reason they would say they were not was if they had ulterior motives to do so. This portion of the research was extremely productive because students asked about issues they had encountered in their research and they knew enough to engage in discussion on the issues. Some of the subjects had direct knowledge of the cases, and others were deeply involved in criminal justice issues and reform.

\section{CONCLUSION}

This research demonstrates that the coding of the trial transcripts lays the groundwork for a deep understanding of both the common causes and the underlying structural causes of wrongful convictions. Errors we see within the criminal justice system reflect and intensify the problems we see throughout society. The investigation of structural causes using the coding of trial transcripts, beyond the secondary sources, is unique. While structural causes are well recognized, ${ }^{388}$ the trial transcripts facilitated the understanding of them by showing what the juries actually heard and overlooked when convicting the innocent persons.

${ }^{387} \mathrm{Id}$.

${ }^{388}$ Lofquist, supra note 2. 
The Innocence Project and other scholars have identified the traditional canonical factors in their research but pass over the structural factors. The Innocence Project focuses mainly on traditional factors: "misidentification, the misapplication of forensic science, false confessions and use of informants." ${ }^{389}$ An examination of structural causes like racism, justice system culture, and the adversary system may help analyze wrongful convictions, through a focalconcerns perspective. That perspective suggests that "harsher treatment results from stereotypes of racial minorities as more dangerous, more culpable, and less amenable to rehabilitation." 390

The archival research in this study was followed by illuminating interviews of public officials and others who were involved in the cases or reflected social attitudes as reformers. The project also effectively links research and teaching and provides a forum for budding scholars to present fresh insights through the use of original data. This research might be expanded in the future with the coding of transcripts from other cases and with interviews of the official participants.

An example of how the students integrated their knowledge of the theoretical literature and the cases was the in-depth interview with prosecutor, P.F. about wrongful convictions. Rather than search for solutions, P.F. stated that law enforcement misconduct was rare and that false confessions originate from the self-interest of the accused. The students suspected tunnel vision and the adversary system were the underlying reasons for his approach. "A prosecutor who questions the integrity of a police investigation risks straining that relationship . ..."391 The interview also illustrated the issues of tunnel vision and confirmation bias among law enforcement, which are structural issues underlying law enforcement. Students suspected structural racism as one reason for the wrongful convictions of racial minorities in Vermont based on outsider bias.

This research also gives insight into wrongful conviction cases involving false confessions, tunnel vision, and racial profiling. The Central Park Five (Richardson/Wise) and the Roscetti Four (Ollins) cases raised several common themes about the powerful influence of structural racism and tunnel vision in wrongful convictions. Groups of minority teenagers were stereotyped. Almost all of the accused

\footnotetext{
${ }^{389}$ West \& Meterko, supra note 4, at 718, 733.

${ }^{390}$ Spohn, supra note 41.

${ }^{391}$ O’BRIEN \& FINDLEY, supra note 2.
} 
youths gave false confessions. The Deskovic and Washington ${ }^{392}$ cases also involved coercive interrogations of juveniles and intellectually disabled persons.

The findings show that the canonical list of errors in these cases may be just a veneer for deeper structural problems. Minority kids and other disadvantaged persons may have been coerced into confessing due to racial profiling, narrative contamination, tunnel vision, and overzealous misconduct. The finding of the coexistence of structural errors should inspire reform which not only solves the particular error but looks to solving underlying problems through awareness, precautions, and training.

The understanding of the repetitive patterns and root causes of the conviction errors are important to prevent future errors. Without a deeper understanding of the underlying structural reasons for wrongful convictions, the mistakes and misconduct will continue to recur. ${ }^{393}$ The structural issues are not the false confessions or eyewitness identification, per se, but why young Black teenage males are singled out for arrest in the first place. The answer involves racial profiling and zero tolerance law enforcement policies, and the perceived threat of young Black males. ${ }^{394}$ Of course, many falsely accused are white. Their wrongful convictions arise from other systemic flaws such as tunnel vision in police and prosecutor decision making, media biased coverage, electoral politics, and mistreatment of juveniles, discussed above.

By coding trial transcripts for information about what the jury actually heard, beyond the media stories, and by using this information to conduct structured interviews, this study has helped to identify the common structural problems in these cases. It thereby highlights on the kind of reforms which may help to alleviate future error and misconduct.

\footnotetext{
392 Freedman, supra note 77.

${ }^{393}$ Leo, supra note 1, at 207.

${ }^{394}$ Lofquist, supra note 1.
} 